IZA DP No. 5999

Do Women Prefer a Co-operative Work Environment?

Peter Kuhn

Marie Claire Villeval

September 2011

Forschungsinstitut zur Zukunft der Arbeit Institute for the Study of Labor 


\title{
Do Women Prefer a Co-operative Work Environment?
}

\author{
Peter Kuhn \\ University of California, Santa Barbara \\ and IZA \\ Marie Claire Villeval \\ University of Lyon, CNRS, GATE \\ and IZA
}
Discussion Paper No. 5999
September 2011

\author{
IZA \\ P.O. Box 7240 \\ 53072 Bonn \\ Germany \\ Phone: +49-228-3894-0 \\ Fax: +49-228-3894-180 \\ E-mail: iza@iza.org
}

\begin{abstract}
Any opinions expressed here are those of the author(s) and not those of IZA. Research published in this series may include views on policy, but the institute itself takes no institutional policy positions.

The Institute for the Study of Labor (IZA) in Bonn is a local and virtual international research center and a place of communication between science, politics and business. IZA is an independent nonprofit organization supported by Deutsche Post Foundation. The center is associated with the University of Bonn and offers a stimulating research environment through its international network, workshops and conferences, data service, project support, research visits and doctoral program. IZA engages in (i) original and internationally competitive research in all fields of labor economics, (ii) development of policy concepts, and (iii) dissemination of research results and concepts to the interested public.
\end{abstract}

IZA Discussion Papers often represent preliminary work and are circulated to encourage discussion. Citation of such a paper should account for its provisional character. A revised version may be available directly from the author. 
IZA Discussion Paper No. 5999

September 2011

\section{ABSTRACT \\ Do Women Prefer a Co-operative Work Environment?*}

Are women disproportionately attracted to work environments where cooperation rather than competition is rewarded? This paper reports the results of a real-effort experiment in which participants choose between an individual compensation scheme and a team-based payment scheme. We find that women are more likely than men to select team-based compensation in our baseline treatment, but women and men join teams with equal frequency when we add an efficiency advantage to team production. Using a simple structural discrete choice framework to reconcile these facts, we show that three elements can explain the observed patterns in the team-entry gender gap: (1) a gender gap in confidence in others (i.e. women are less pessimistic about their prospective teammates' relative ability), (2) a greater responsiveness among men to instrumental reasons for joining teams, and (3) a greater "pure" preference for working in a team environment among women.

JEL Classification: $\quad$ C91, J16, J24, J31, M5

Keywords: gender, cooperation, self-selection, confidence, experiment

Corresponding author:

Peter Kuhn

Department of Economics

University of California, Santa Barbara

2127 North Hall

Santa Barbara, CA 93106-9210

USA

E-mail: pjkuhn@econ.ucsb.edu

\footnotetext{
* We are grateful to Philip Babcock, Uri Gneezy and Matthias Sutter for comments on an earlier version of this paper. We thank Sylvain Ferriol for programming this experiment.
} 


\section{Introduction}

A considerable body of recent research has shown that women tend to shy way from competitive work environments, and often perform worse than men when placed in those environments (see for example Gneezy, Niederle and Rustichini, 2003; Gneezy and Rustichini, 2004; and Niederle and Vesterlund, 2007). This aversion to competition is sometimes offered as an explanation for the continuing underrepresentation of women in certain well paid jobs, or in parliaments in modern societies.

If, indeed, women's talents are sometimes wasted because they avoid competitive work environments, it seems important to know which types of work environments are attractive to them. In this paper we study whether women are disproportionately attracted to a work environment where cooperation rather than competition is rewarded, i.e. team production. ${ }^{1}$ In our real-effort laboratory experiment participants can choose either to receive an individual piece rate, or to receive an equal share of a group's output, after experiencing each compensation scheme successively. In many respects, the design of our experiment is similar to Niederle and Vesterlund's (2007) study of selection into competitive environments.

Aside from filling an obvious gap in a literature which has focused almost exclusively on preferences for competition, we argue that studying gender and selection into cooperative work environments is at least as fundamental to understanding gender gaps in the labor market: While relative rewards are in most cases an optional feature of the compensation package, ${ }^{2}$ an almost inevitable feature of joining any firm, work group or partnership is that joining any group ties the fate of its members together: each member's welfare will typically depend positively on the

\footnotetext{
${ }^{1}$ Note that there are also settings where cooperation and competition are not mutually exclusive. Within-group cooperation may be all the more important to succeed in inter-group competition (see for example Bornstein, Gneezy, and Nagel, 2002).

${ }^{2}$ Indeed, much of the early literature on tournaments attempted to characterize the conditions under which firms should choose competitive reward schemes such as tournaments, over simpler compensation methods such as piece rates.
} 
efforts and abilities of her co-workers. In addition, explicit team structures have become an increasingly important component of many workplaces (Hamilton et al., 2003, Boning et al., 2007). Viewed this way, the process of partnership formation is central to the organization of economies (Brown, Falk and Fehr, 2004; Charness and Dufwenberg, 2006; Charness and Yang, 2008). More broadly, the management of cooperation is certainly as central as the management of competition in all human and non-human societies. To our knowledge, with the exception of Boschini and Sjogren (2007), Dargnies (2010), and Healy and Pate (2011), no one has studied how this process varies by gender, at least from an economic point of view.

While it might be tempting to imagine that women are disproportionately attracted to cooperative work environments and outperform (or at least match) men in them because they have more other-regarding preferences than men in an environment favoring free-riding, our results are more complex than this. On the one hand, we do find that women are more likely to select team-based compensation in our baseline condition, where team production offers no efficiency advantages over individual production. At least half of this gap is explained, however, not by an intrinsic preference for the team environment but by women's more optimistic expectations of their teammates' relative ability. On the other hand, women and men join teams with equal frequency when we introduce an instrumental reason for joining teams, in particular an efficiency advantage to team production. Using a simple structural discrete choice framework to reconcile these facts, we find that the simplest model that can adequately account for all of them requires three key elements: (1) a gender gap in confidence in others (i.e. women are more optimistic about their prospective teammates' relative ability), (2) a greater responsiveness among men to instrumental reasons (i.e. the prospect of increased financial reward) for joining teams, and (3) a greater "pure" preference for working in a team environment among women. 
Other findings of the paper include the following. First, despite reducing the marginal private rewards to effort by 50 percent, and despite the fact that the interactions in our experiment are anonymous and one-shot, team compensation does not cause any free riding in our experiment (as in Balafoutas and Sutter, 2011). This lack of moral hazard applies both to individuals' actual effort choices, and to individuals' expectations of their partner's behavior. While this lack of free riding could be attributable to a number of features of our design, ${ }^{3}$ it is convenient for our purposes because evidence suggests that, for a variety of reasons, free riding is also rare when teams are used in real workplaces (e.g. Hamilton et al. 2003; Boning et al. 2007). ${ }^{4}$ Thus, our design allows us to focus on other factors affecting the decision to choose a team-based environment, including pure preferences for the team environment and beliefs about adverse selection, which may be more relevant in real-world decisions.

Second, in contrast to moral hazard, adverse selection (and participants' concerns about it) play a crucial role in determining selection into teams in our experiment. Consistent with the simplest payoff-maximizing model, both men and women are more likely to avoid teams as their own ability rises, and as their assessment of their teammate's ability falls. This finding contrasts with Hamilton, Nickerson and Owan (2003)'s natural experiment, where abler workers tended to join teams earlier than other workers, but is consistent with Kocher et al. (2006) in which participants who choose not to join a team for playing a beauty-contest game exhibit more

\footnotetext{
${ }^{3}$ For example, it is possible that in real settings, free-riding develops only after several days or weeks of interactions. The duration of a typical real-effort experiment may not be long enough to allow the development of free-riding.

${ }^{4}$ Free riding is, of course, a common outcome in public goods experiments (see Ledyard 1995, and Plott and Smith 2008, chapters 82-90). In contrast to our design, virtually all public goods experiments involve groups of three or more. Participants' contributions rarely involve real effort, and players typically receive feedback on their coparticipant's contributions during the experiment. Explanations that have been offered for the lack of free riding in real workplace teams include mutual monitoring and peer pressure (Kandel and Lazear 1992). In essence, our approach (correctly, in our view) treats the moral hazard problem in workplace teams as solved, and focuses on other key factors affecting the team choice decision.
} 
sophisticated plays. As noted, since women are more optimistic about their teammate's ability in our game, this explains part of women's greater selection into teams.

Third, women's decision to join a team (though not necessarily the rate of actual team formation) is more frequent when both parties must agree to join for the team to be formed, compared to a condition in which voluntary team joiners are matched with a random participant in a mandatory team treatment. In our assessment, the two most likely reasons for this pattern are (a) the belief that the team environment will increase the teammate's motivation, and/or (b) a "letting down the team" effect (Babcock et al. 2011): female participants are reluctant to disappoint a prospective teammate who has also selected the "team" option. In addition, we find that the social aspect of teams -represented in our experiment by the opportunity to communicate by instant messenger with the teammate- plays no significant role in the gender gap in team formation. Also irrelevant is the teammate's gender: participants' assessments of their teammates' ability are unrelated to the teammate's gender, as are decisions to join teams. This is in contrast with studies on competitiveness showing that the partner's gender influences decisions or performance (see notably Gneezy et al., 2003 and Datta Gupta et al., 2011).

Finally, we find that men and women perform equally well on teams (both absolutely and relative to individual compensation) when all participants are forcibly assigned to team compensation. But when subjects are free to choose between team and individual compensation, the mean performance of the voluntarily-formed teams is lower than performance of individuals who choose to work individually. This output gap is entirely due to adverse selection into teams, which is stronger among men than women. Thus, voluntarily-formed female teams outperform voluntarily-formed male teams. In this sense, voluntary team formation may work better in female workplaces: the teams that form will be less likely to consist of 'lemons'. Perhaps this 
helps explain the lack of adverse selection in Hamilton et al.'s garment factory study, where almost all the employees were female.

The remainder of this paper is organized as follows. Section 2 presents the related literature. Section 3 details the experimental design. We present our descriptive statistics in Section 4 while Section 5 develops a structural model estimating underlying team preferences and responses to efficiency gains. Section 6 focuses on gender and performance in endogenously-formed teams. Section 7 concludes.

\section{Related Literature}

To our knowledge, the first economics experiment on gender and competition was performed by Gneezy, Niederle, and Rustichini (2003), who found that women appear to be less effective than men in competitive environments, despite the fact that their performance is similar to men's when the environment is noncompetitive. This result has been confirmed for a variety of tasks and subject populations, including for example Gneezy and Rustichini (2004), a field experiment involving 40-meter races with school children.

Concerning selection into competitive environments, Niederle and Vesterlund (2007) provide evidence that women "shy away" from competition in a task involving adding up sets of two-digit numbers. Men are much more likely to enter a payoff-equivalent tournament than women, and the authors attribute this both to gender differences in overconfidence and tastes for competition. Gneezy, Leonard, and List (2009) show that this gender difference is reversed in experiments performed in a matrilineal society, suggesting that it is at least in part cultural. Along the same lines, Booth and Nolen (2009a,b) show that girls who attended same-sex schools are less risk- and competition-averse than those who attended coed schools. Sutter and Rützler (2010) observe gender differences in competition very early in life (among three-year-olds), while Garratt, Weinberger and Johnson (2011) find especially large differences among persons 
over 40 years of age. Datta Gupta, Poulsen and Villeval (2011) study the effects of the prospective partner's gender on decisions to enter a tournament and Sutter et al. (2009) study gender pairing in bargaining. On the other hand, Wozniak, Harbaugh, and Mayr (2010) investigate the effects of hormonal fluctuations on tournament entry decisions.

Compared to the literature on gender and tournaments, the literature on gender and teams is remarkably sparse. Turning first to gender performance differences in exogenously-formed teams, we are aware of only three studies in the economics literature. ${ }^{5}$ Ivanova-Stenzel and Kübler (2011) find significant gender differences in effort in mixed-sex teams, with men working harder. Delfgaauw et al. (2009) study the effects of sales competitions between teams in a chain of Dutch retail stores. They find that inter-team competition only raises sales when a large fraction of the employees are of the same gender. Finally, Apesteguia, Azmat and Iriberri (2010) study a large business game, played in groups of three; they find that teams formed by three women are significantly outperformed by any other gender combination. They attribute this result, in part, to poor work dynamics within the all-female teams.

Gender differences have also received attention by economists in the context of public goods games, which are closely related to the team production problem. A recent survey of these results is provided in Table 4 of Croson and Gneezy (2009) (see also Eckel and Grossman, 2008). The results do not show robust gender differences, though we note that the context is very different from ours: 'Teams' have 4 or 5 members, the individually rational contribution level is zero, and there is no real-effort task. In a recent cross-cultural study, however, Andersen

\footnotetext{
${ }^{5}$ While there is a large and active literature in psychology and management science on gender and team performance, most of it is based on observational studies of behavior in existing teams (not self-selection into teams), and teams are rarely incentivized (see Graves and Powell, 2007, for a recent review).
} 
et al. (2009) find more public-goods provision in matrilineal societies, with most of the difference driven by differences in male public goods contributions between the societies. ${ }^{6}$

To our knowledge, only three papers study gender differences in the tendency to join teams (i.e. to enter situations in which compensation is based on the performance of the group rather than the individual). Boschini and Sjogren (2007) study co-authorship patterns in economics, with a focus on gender-matching patterns in co-authorship and not on the decision to co-author itself. Dargnies (2010) studies the decision to enter a team but in the context of a tournament between teams. She finds that while women are just as reluctant to enter a team tournament as an individual tournament, males - especially the high-performing ones- are less willing to enter a team tournament than an individual one because they dislike the uncertainty about their teammate's ability. Healy and Pate (2011) find that women prefer competing in teams whereas men prefer to compete as individuals. In contrast to these studies, we eliminate all dimensions of competition between teams in our design in order to concentrate purely on the attraction exerted by cooperative settings on compensation choices.

A handful of other studies have examined the team-formation process in a situation where both adverse selection and moral hazard can affect team performance, without focusing on gender differences. For example, contrary to what simple selection models would predict, in Hamilton, Nickerson and Owan's (2003) well-known field study of a textile plant, strong assortative matching did not occur when work teams were formed by mutual consent; nor was free-riding a significant problem. In contrast to their results, we find that adverse selection plays a large role in decisions to join a team, with abler workers more reluctant to join teams. Our

\footnotetext{
${ }^{6}$ Economists and psychologists have also studied gender differences in other simple strategic interactions, including ultimatum games, dictator games, trust games and prisoner's dilemma games. According to Croson and Gneezy (2009, pp. 455-462), few robust differences have been identified, though women's behavior in all of these games appears to be more context-specific than men's. Interestingly, we find that men's team-joining behavior is actually much more responsive to situational factors (in particular the size of the efficiency gains from team production and information about their prospective partner's ability) than women's.
} 
results are consistent with those of Kocher et al. (2006) in which the players who choose to join a team instead of playing individually a beauty-contest game also deviate more from the equilibrium. In a field experiment involving farmworkers, however, Bandiera, Barankay and Rasul (2009) did find that when the incentives facing an entire team are strengthened, assortative matching into teams by ability is increased.

\section{Experimental Design}

The design is partly inspired by Niederle and Vesterlund (2007). At the beginning of each session, we elicit the participants' risk attitudes by using the Holt and Laury (2002) procedure. ${ }^{7}$ Then, each participant enters his/her first name on the computer before being paired with another participant who is located in another room; in essentially all cases this revealed the participant's gender. ${ }^{8}$ Participants remain paired with the same co-participant for the entire session. The physical location and timing of participants' arrival and departure from the two rooms was arranged to make it extremely unlikely they would ever see any participant from the other room.

In a session, participants have to perform a task during sequences of 4 minutes. This task consists of decoding numbers into letters according to a code that changes repeatedly (see instructions in Appendix A). Before the experiment begins, participants are given three minutes to practice the task. At any time, participants have the option to read magazines or to surf the Internet instead of performing the task by pressing a button on their computer screen (this was made common information in the instructions but only one participant used this opportunity for

\footnotetext{
7 The participants have to make 10 successive choices between two paired lotteries, "option A" and "option B". The payoffs for option $A$ are either $€ 2$ or $€ 1.60$, whereas the riskier option B pays either $€ 3.85$ or $€ 0.10$. In the first decision, the probability of the high payoff for both options is $1 / 10$. In the second decision the probability increases to $2 / 10$. Similarly, the chance of receiving the high payoff for each decision increases as the number of the decision increases. A risk neutral participant should cross over from option A to option B at the fifth decision.

${ }^{8}$ We were careful not to invite people with gender-neutral names. All participants, except four (all men), reported their true name (this could be checked with the list of participants registered in each session). Three participants changed their name but kept a male name. One participant chose a pseudo that was not a name ("be nice and shut up"); identification of the gender could have been more difficult.
} 
only a few seconds). Each session consists of six parts, always in the same order. One of these six parts is randomly selected for payment at the end of the session. Participants observe their own outputs in all parts but do not learn their co-participant's actual output in any part until the very end of the session, when payoffs are made. Immediately below, we describe the entire experimental design for the baseline (B) treatment. Aspects that were changed for our efficiency advantages (EA) treatment are described after that.

\section{The Baseline treatment}

Parts 1 and 2 of the experiment are designed to provide baseline measures of our participants' task performance in the individual and team environments respectively. Specifically, in Part 1 participants are paid a piece rate: each participant's pay for this part (if this part is selected for actual payment) is given by $Y_{i}{ }^{I}=r^{I} Q_{i}{ }^{l}$, where $Q_{i}{ }^{1}$ is his own output. We set $r^{I}=20$ Euro-cents. In Part 2, participants are teamed with their co-participant to perform the task; they share the output of the team equally. In other words, individual $i$ is paid $Y_{i}^{T}=r^{T}\left(Q_{i}{ }^{l}+\right.$ $\left.Q_{i}^{2}\right) / 2$ for her work during this period, where $Q_{i}^{2}$ is her co-participant's output. Throughout the baseline treatment, we set $r^{T}=r^{I}=20$ Euro-cents; thus there is no efficiency advantage to team production. For any convex disutility-of-effort function, individually rational behavior in the baseline treatment implies that participants should exert less effort in the team setting than the individual piece rate, and -unless they expect their teammate to be much abler than themselves - to avoid teams whenever possible.

The purpose of Parts $\mathbf{3}$ and $\mathbf{4}$ is to study participants' revealed preference for teamwork in the simplest possible environment, i.e., one in which their choice to be in a team environment actually ensures that they will be on a team. To this end, in Part 3 participants can choose between being paid an individual piece-rate (as in Part 1) or according to a team-based payment scheme (as in Part 2). Then, they perform the task. If they have chosen teamwork, their 
performance in this part is added to the output of their co-participant in part 2; this provides a guaranteed 'partner' for all participants who choose the team environment. This is clearly explained to the participants, and comprehension tests indicate it is well understood.

In Part 4, participants do not perform the task. They are simply asked to submit their Part 1 output (and that of their co-participant) to a team or individual payment scheme. Our motivation was to test for subjects' expectations of free-riding by their partner: If they expected their partner to free-ride when on a team, they should be more willing to choose team production based on their partner's Part 1 output (when he is paid individually) than on his Part 2 output.

Between Parts 4 and 5 we administer a short interim questionnaire. Participants are asked to estimate the number of problems they believe their co-participant solved correctly in Parts 1 and 2. They are rewarded 50 Euro-cents for each correct answer (plus or minus one unit). We also elicit the participants' confidence in these estimates by asking them to self-report their confidence on a five-level Likert-type scale.

The purpose of Parts 5 and 6 is to study participants' team preferences in a richer context that more closely mimics the real-world process of team formation. Here, a team is formed only if both co-participants choose the team compensation scheme, and participants are paid based on both partners' actual performance in those teams that are successfully formed. ${ }^{9}$ Part 6 is the same as Part 5, except that after teams are formed (but before production occurs), participants who have agreed to form teams are given two minutes of unstructured time during which to exchange instant messages. ${ }^{10}$ Participants are informed of this opportunity before they choose their compensation mode. The motivation for this part was to see if the opportunity to

\footnotetext{
${ }^{9}$ Another new feature of Parts 5 and 6 is that subjects learn whether their co-participant selected team-based pay before selecting their effort levels. Thus, they have an opportunity to 'reward' their partner for joining the team. Again, this is an important feature of most real-world team-formation decisions.

${ }^{10}$ Communication occurs after the payment scheme has been chosen because we wanted to create a more social team environment, but we were not interested in how the participants' choices to join the team could be directly influenced by communication.
} 
socialize affects team membership and performance. In order to keep participants' choices confidential within rooms, we gave all participants an option to type text on their computer during this period.

Figure 1 summarizes the time structure of the game.

\section{(Insert Figure 1 about here)}

\section{The Efficiency Advantage treatment}

This treatment is identical to the B treatment, with the exception that team production has now a 10 percent productivity advantage over individual production. Specifically, the individual piece rate remains the same at $r^{I}=20$ Euro-cents, but the team piece rate is raised to $r^{T}=22$ Euro-cents. The purpose of the Efficiency Advantage (EA) treatment is, again, to study selection into teams in a more realistic setting, one in which there might be aspects of the production technology that make production in groups more efficient (e.g. Lazear 1999).

\section{Procedures}

The experiment consists of 10 sessions conducted at the laboratory of the GATE (Groupe d'Analyse et de Théorie Economique) institute in Lyon, France. We invited undergraduate students from the local engineering and business schools via the ORSEE software (Greiner, 2004). Due to no-shows, between 14 and 20 individuals actually took part in each session, for a total of 174 participants. The B treatment was implemented in 5 sessions involving 86 participants ${ }^{11}$ and the EA treatment in 5 sessions with a total of 88 participants. We organized only gender-mixed sessions. To guarantee a balance between genders, the number of participants of each gender could not deviate by more than 2 from the other gender. In the B treatment, we have collected 16 individual observations of women paired with women, 14 individual

\footnotetext{
${ }^{11}$ Due to a technical breakdown, we lost completely the observations of two pairs of participants in one session of the B treatment and we had to stop this session after Part 4. We include in our analysis the data from Parts 1 to 4.
} 
observations of men paired with men, and 56 observations of persons in mixed pairs. In the EA treatment, the corresponding values are 22,24 , and 42 , respectively.

We used our two contiguous laboratories ("Regate 1" and "Regate2”). To preserve anonymity, upon arrival the first 9 participants were assigned to a room and the next ones were directed to the other room and we proceeded to the necessary adjustments before distributing the instructions. ${ }^{12}$ As such, since people never interact with other individuals from the same room, two or more friends showing up at the same time could not be paired together.

The experiment was computerized, using the REGATE software (Zeiliger, 2000). The participants first received the instructions for the Holt and Laury (2002) test. Then, after the decisions were completed, the instructions for the main task were distributed. These instructions specified that there would be six parts and that one of these parts would be selected for payment at the end of the session, but only the instructions for the Part 1 were included. They stated that the participants were allowed to read magazines or to use the Internet at any time instead of converting letters into numbers. A quiz was used to check the understanding of the instructions and answers were checked individually. Once questions were answered in private, participants practiced during three minutes to familiarize themselves with the task. Then, they were required to enter their first name in the computer and after being randomly paired with a participant located in the other room, they were informed of the first name of this co-participant; they knew that they would be paired with the same participant throughout the session. The instructions for each new part and for the interim questionnaire were distributed after completion of the previous part. At the end of Part 6 and after completion of an exit questionnaire, the participants of the

\footnotetext{
${ }^{12}$ After 18 participants had shown up, we directed the 19th participant to the first room and the 20th to the second room. If fewer than 18 participants showed-up, we moved participants from Regate 1 to Regate 2 to make sure that we had the same number of participants in both rooms. An alternative option would have been to put all the females in one lab and all the males in the other lab, but this might have made gender highly salient to the participants. Aside from asking subjects to use their real first names, all of our instructions and procedures were carefully designed to draw as little attention to the subjects' genders as possible.
} 
first lab were allowed to proceed to the payment room. Once these were paid, the participants located in the other lab were invited to move to the payment room.

On average a session lasted 75 minutes and participants earned $€ 16.66$ in the baseline and $€ 17.23$ in the EA treatment, including a $€ 3$ show up fee and the payment of correct predictions.

\section{Beliefs, preferences and team choices: preliminary findings}

In this section we first study the gender differences in perceptions and performance in Parts 1 and 2 of the experiment, where assignment to a compensation scheme (individual versus team) is mandatory. We then analyse particpants' choices of compensation schemes in the teamchoice Parts of the experiment (Parts 3 though 6) where participants could voluntarily choose their compensation scheme.

a) Gender differences in beliefs and performance

As noted, in Parts 1 and 2 of our experiment we forcibly allocate all participants to individual and team production respectively to provide baseline measures of performance and behavior in the two schemes. Table 1 shows participants' mean output levels in these parts by gender and for the B and the EA treatments respectively. It also displays the $p$-values from $t$ tests for differences between the means. ${ }^{13}$

\section{(Insert Table 1 about here)}

Table 1 confirms, first of all, that our experimental task is indeed gender neutral: there is no significant difference in output between men and women when they receive individual piece rates. This gender neutrality extends to performance in teams, irrespective of whether team production has efficiency advantages over individual production. The gender neutrality of this

\footnotetext{
${ }^{13}$ Kolmogorov-Smirnov tests of equality of distributions were also done, with no qualitative differences in outcomes.
} 
task in our setting is consistent with other experiments using this task (see Charness, Masclet, and Villeval, 2010, albeit using a flat compensation scheme).

The other key finding from Table 1 is that, despite the anonymous nature of interactions in this experiment and the fact that participants do not learn their partner's performance in any part until the conclusion of the entire experiment, participants do not free ride on their partners when teams are formed. In fact, if anything the data show an increase in task performance between Parts 1 and 2. ${ }^{14}$ The lack of free riding is, in some ways, quite astonishing in view of the fact that the private financial return to extra effort is halved in the team case, relative to the piece rate. This result is consistent, however, with a number of studies that show superior productivity in teams despite the potential for free riding (see for example Knez and Simester 2001, Hamilton et al. 2003, and Babcock et al. 2011).

Table 2 shows participants' mean beliefs concerning their co-participant's performance in Parts 1 and 2, elicited from the interim questionnaire described earlier. They show that, not only was there no free riding in teams, participants did not expect any free riding in teams either. Specifically, if the participants expect their partner to free ride in the team setting, they should expect a lower level of output from him/her in Part 2 than in Part 1. This is decidedly not the case; in fact they expect a small, but statistically significant improvement in their partner's performance in the team setting.

The other key finding from Table 2 is a highly significant gender gap in expectations of the partner's ability: As a number of other studies (including Niederle and Vesterlund, 2007) have found, both men and women expect their partner to be less able than themselves.

\footnotetext{
${ }^{14}$ This increase could, in part, be due to learning the task. However, this task is very simple and participants had a three-minute practice period. In Charness, Masclet and Villeval (2010), an increase in performance was observed between periods 1 and 2, but there was no practice before participants played the first period. Since the increase occurs under both treatments in our game, it cannot be a result of raising the piece rate from 20 to 22 , since this only occurs in the EA treatment.
} 
Strikingly, however, even though this task is demonstrably gender neutral, men have much lower expectations of their partner's ability than women. This gender gap in expectations is highly statistically significant. $^{15}$

\section{b) Team choice in the Baseline treatment}

The share of men and women who choose team compensation in the B treatment (where there is no efficiency advantage to team production) is shown in Figure 2. Results are shown for Parts 3 through 6 of the experiment, i.e the team-choice Parts where participants were free to choose their compensation scheme.

\section{(Insert Figure 2 about here)}

According to Figure 2, female participants elected to receive team-based pay more frequently than male participants in all of the team-choice parts of the experiment. The difference is statistically significant at the five percent level or better in two of the four cases, and it is borderline in Part 6. Using the total number of times (from zero to four) a participant selected team-based pay as a crude indicator of a participant's overall behavior, women chose teams an average of 1.18 times compared to .43 times for men $(p=.007)$. Aside from the possible role of gender differences in beliefs (which we examine below), Part 3 of the B treatment provides the cleanest and simplest measure of the gender gap in pure preferences for a teambased work environment in our main experiment. It shows women choosing teams three times as often as men, a difference which is significant at the 5 percent level.

Comparing Parts 3 and 4, there is no indication that participants expected a moral hazard problem in the team environment: in fact, women selected team compensation less frequently in

\footnotetext{
${ }^{15}$ One might wonder whether participants' perceptions of their partner's ability depend on the partner's gender as well. This issue is explored in Table A1 in Appendix 2, which shows that neither actual performance, nor perceived partner performance, depend on the partner's gender. Thus, men's overconfidence in our study is not 'sexist' in the sense that men (or women) systematically underestimate women's competence; instead men's overconfidence applies equally when men are comparing themselves to other men, or to women.
} 
Part 4, despite the fact that Part 4 protects them against free riding by pairing them with their coparticipant's output under the individual piece rate. Men, on the other hand, selected teams slightly more in Part 4, though for both men and women the difference between their Parts 3 and 4 behavior is statistically insignificant ( $p=.262$ for women and $p=.570$ for men, two tailed). Comparing Parts 5 and 6, there is no indication that women were more attracted to teams when the team experience was more interactive. In fact, women selected team compensation less frequently in Part 6 but insignificantly so $(p=.767)$, despite the fact that Part 6 allows for a period of communication between the team members prior to production. ${ }^{16}$ Men, on the other hand, selected teams significantly more often in Part 6 than in Part 5 ( $p=.044)$. This difference could be due to gender differences in communication preferences (Friebel and Seabright, 2011).

Finally, comparing Parts 3 and 5, we find essentially no difference in men's behavior (team pay was chosen 10.81 versus 7.14 percent of the time, $p=.160$ ), but women are much more likely to choose teams (41.03 versus 22.73 percent of the time, $p=.033$ ) when team production requires both partners to select the team environment. ${ }^{17}$ One possible reason for this is that female participants expect advantageous rather than adverse selection into teams; this would occur if participants' expectation of their co-participant's output given that he or she selects team compensation exceeds the expected output of a randomly selected participant. We think this is unlikely given the strong evidence for adverse selection into teams in our experiment for both men and women. ${ }^{18}$ A more likely explanation, in our assessment, is a "letting down the team"

\footnotetext{
${ }^{16}$ Importantly, choosing individual compensation in Part 6 did not allow individuals to finish the experiment earlier by avoiding this communication period; all participants had to wait till the communication period was ended before beginning Part 6 production.

${ }^{17}$ At 6.8 percent, the share of women who ultimately 'formed' a team was, not surprisingly, actually lower in Part 5 than in Part 3. For men, team formation was the same in Parts 3 and 5, at 7.1 percent.

${ }^{18}$ A distinct but related possibility is that individuals anticipate that their co-participant will reward them with higher effort for their choice of team-based compensation if a team is formed. We do not find support for this hypothesis in Section 6.
} 
effect, as described in Babcock et al. (2011); we discuss this possibility further in our analysis of the EA treatment results below. ${ }^{19}$

To shed some additional light on participants' choices of team compensation in each of Parts 3-6, Table 3 presents some simple regression results that control for individual ability, beliefs about partner ability, and risk attitudes. ${ }^{20}$ Table 3 uses the participant's own actual performance in Part 1 as a measure of his/her ability, and his/her estimates of his/her partner's Part 1 performance to measure expected partner ability. ${ }^{21}$

\section{(Insert Table 3 about here)}

In all team-choice parts of the experiment, Table 3 shows that abler participants were less likely to choose the team environment, consistent with the basic adverse selection hypothesis. This effect is statistically significant in 4 of the 5 columns, and highly so (at 1\%) in three of those cases. Also, as predicted, in most columns individuals were more likely to select team compensation when they expected their teammate to be more able, though this effect is statistically significant in only two of the 5 cases (possibly due to the small share of participants choosing teams, especially for men). As we show below, this changes substantially in the EA treatment.

Turning to the gender coefficients and focusing first on Part 3, we notice a positive but insignificant female coefficient of 9.72 percentage points. Thus, when we add statistical control

\footnotetext{
${ }^{19}$ A final difference between Parts 3 and 5 is that the probability of actually receiving team-based compensation, given a choice of team compensation, is less than one in Part 5. See Section 5 (specifically footnote 25) for a discussion of how this affects subjects' predicted choices and the interpretation of our results.

${ }^{20}$ Risk aversion could affect decisions to join teams, though its predicted effects are ambiguous in sign. On the one hand, if there is a lot of part-to-part variation in individual task performance, greater risk aversion might lead participants to prefer teams, since being paid the average of the two workers' performance adds an element of insurance. On the other hand, uncertainty about the ability (or intentions) of one's teammate will work in the opposite direction. Thus, we added our elicited Holt-Laury measure of risk aversion (the switching point from the safer to the riskier lottery and a dummy for multiple switching points) to our controls. It never had a significant effect. We also detected no statistically significant gender gap in risk aversion in our subject pool.

${ }^{21}$ Arguably we could use expectations of their partner's part 2 output, since this reflects his/her performance in a team environment. We discuss this issue in more detail when introducing the structural model in the following section. In practice, given the lack of free riding in our experiment it makes no difference which measure we use.
} 
for perceived partner ability to the comparisons of means in Figure 1, women's higher propensity to choose team compensation falls in magnitude and becomes statistically insignificant. ${ }^{22}$ Both the estimated female coefficient and the coefficient on beliefs are, however, rather unstable across columns of Table 3, suggesting that the B treatment data alone are not rich enough - partly because so few subjects of either gender select team compensation- to distinguish these two possible sources of the unadjusted gender gap in team choices. For this reason, we postpone further analysis of the relative role of beliefs versus intrinsic preferences for teamwork to Section 5, when we introduce additional data from the EA treatment, plus some simple structural assumptions.

In sum, women select the team option more frequently than men in the baseline case; at least part of the explanation is the fact that women are more confident about others' relative ability. The latter tendency has, of course been observed in a number of contexts (e.g., Schwieren and Sutter, 2008, who refer to it as women's greater 'trust in another subject's ability"), but to our knowledge we are the first to link it to the partnership formation decision.

\section{c) Team choice in the Efficiency Advantage treatment}

Figure 3 displays the share of participants who choose team compensation in the EA treatment.

\section{(Insert Figure 3 about here)}

Two features of the results are immediately apparent: First, despite only a small improvement in efficiency associated with team production, the share of both men and women choosing team compensation is much higher than in the B treatment. Indeed, in all cases the new

${ }^{22}$ Put a different way, if one excludes the belief about the partner's ability from the Table 3, Part 3 regression, the gender coefficient is 17.11 percentage points and is significant at the $5 \%$ level). 
rates of team choices are above 50 percent. $^{23}$ Second, the gender gap in team selection essentially vanishes: although women still choose teams more frequently than men, the gap is much smaller in magnitude and statistically insignificant as men's propensity to choose team compensation rises much more between the B and EA treatments. In some sense, therefore, men are more responsive to the introduction of these extrinsic benefits of being on a team.

Comparing Parts 3 and 4 of the EA treatment, there is once again no indication that participants expected a moral hazard problem in the team environment ( $t$-tests, $p=.743$ for women and $p=.253$ for men, two-tailed). Comparing Parts 5 and 6, there is now no indication that participants of either gender were more attracted to teams when the team experience was more interactive $\left(p=.421\right.$ for women and $p=1.0$ for men). ${ }^{24}$ For both these reasons, starting with the next section we will ignore moral hazard concerns and the effects of communication and focus our analysis of selection into teams on the two 'main' conditions: Part 3 and Part 5, i.e. matching with the teammate's previous output, and matching with the teammate's current output.

Finally, comparing Parts 3 and 5, we again find that women are more likely to choose teams (76.74 versus 53.49 percent of the time) when team production requires both partners to select the team environment, a difference which is highly significant ( $p=.003)$. For men, this difference is smaller (68.89 versus 55.56 percent of the time) and only marginally significant ( $p=.083)$ (it was insignificant in the B case). This provides further support for the "letting down the team" effect (Babcock et al., 2011), especially for women. ${ }^{25}$ Although Babcock et al. do not

\footnotetext{
${ }^{23}$ It is perhaps worth noting that, with a 10 percent efficiency advantage to team production, the marginal private return to effort in teams rises from 50 to 55 percent of the marginal return to effort under individual compensation. Thus, in a 'standard' model, we should still expect high levels of free riding in teams, and would therefore still expect most if not all participants to rationally avoid the team environment.

${ }^{24}$ All of the differences mentioned are small in magnitude and none are statistically significant at conventional magnitudes. Perhaps an effect of interaction would be found if we allowed for collaboration on the work task itself. ${ }^{25}$ This interpretation is mildly supported by the evidence from an exit questionnaire where 21.21 percent of the women choosing the team compensation in Part 5 justify their choice by the willingness not to disappoint the partner in case s/he wanted to form a team; only 16.13 percent of men invoke this reason (the difference is, however, not significant $(p=.609)$.
} 
report a gender gap, our finding that the effect is stronger among women is consistent with their finding that it is confined to individuals who are less able than their teammates, since women perceive themselves to have lower relative ability than men in our context.

An interesting result from the exit survey is that while men's self-reported motivations for choosing a team are stable through Parts 3 and 5, some motivations of women vary. Indeed, the belief that "the partner would be quite good at the task" motivated 60.87 percent of women to choose team compensation in Part 3 but only 36.36 percent of them in Part 5 (the corresponding percentages for men are 60 and 54.84). In contrast, the belief that "being on a team might motivate my partner more" is cited by 13.04 percent of women in Part 3 and by 30.30 percent in Part 5 (32 and 35.48 percent of men, respectively). Women seem to believe that the fact that team production requires both partners to select the team environment creates an additional source of motivation.

Parallel to Table 3 in the B treatment, Table 4 presents some simple regression results for choice of team compensation in the various parts of the EA treatment.

\section{(Insert Table 4 about here)}

In all of the team-choice parts, Table 4 shows that abler participants were less likely to choose the team environment, consistent with the basic adverse selection hypothesis. This effect is highly statistically significant in all columns. Also consistent with this hypothesis, participants were more likely to select team compensation when they expected their teammate to be more able. In contrast to the B treatment, this effect is now always highly significant, and appears to be equal in magnitude (but opposite in sign) to the effect of own ability. Also in contrast to the B treatment, the female coefficient is now almost never significant (except in Part 3 where it is marginally significant), with some of the point estimates now negative rather than positive. 
In sum, Table 4 provides additional support for the notion that concerns about adverse selection play a major role in the decision to join teams. Further, these concerns interact with gender in an important way because women, on average, are more optimistic about their prospective teammates' abilities (irrespective of that teammate's gender). However, in contrast to the B treatment, the estimated female coefficient is now indistinguishable from zero in most parts. To some extent this should not be surprising because these data incorporate the effects of additional extrinsic factors (efficiency advantage to team production) that are not present in the B case, and because a comparison of the two cases suggests that men may be more responsive to these extrinsic factors than women. In the following section, we attempt to sort out the relative importance of these effects using a simple structural model of preferences that allows all of them to operate within a common framework that tries to explain the results from both our treatments.

\section{Reconciling the Results from both Treatments: A Structural Model of Preferences for}

\section{Teamwork}

\section{a) The model}

Suppose that the utility of individual $i$ if s/he works on a team $(T)$ versus individually ( $I$ ) is given respectively by:

$$
\begin{aligned}
& U_{i}^{T}=a^{T}+b^{T} F_{i}+c Y_{i}^{T}+\varepsilon_{i}^{T} \\
& U_{i}{ }^{I}=a^{I}+b^{I} F_{i}+c Y_{i}^{I}+\varepsilon_{i}^{I},
\end{aligned}
$$

where $F_{i}$ is an indicator for being female, $Y_{i}^{T}$ is the individual's expected cash payoff if he/she works on a team, $Y_{i}^{I}$ is the individual's expected cash payoff if he/she works individually, and the $\varepsilon$ 's represent the unobserved component of individuals' tastes for the two options. ${ }^{26}$ If (1) and (2) fully describe our participants' utilities, participant $i$ will choose team compensation iff:

\footnotetext{
${ }^{26}$ Note that, for ease of exposition, (1) and (2) do not index $c$ by gender (i.e. men and women care equally about financial gains, relative to other aspects of the compensation package) ; we relax this assumption later in this section.
} 
$\varepsilon_{i}<a+b F_{i}+c\left(Y_{i}^{T}-Y_{i}^{I}\right)$

where $\varepsilon_{i}=\varepsilon_{i}^{I}-\varepsilon_{i}^{T} ; a=a^{T}-a^{I}$; and $b=b^{T}-b^{I}$. If $\varepsilon_{i}$ is independently and normally distributed, then equation (3) describes a probit regression where the outcome, $T_{i}$, equals one if the participant selects team compensation and zero otherwise. The coefficient, $b$, on an indicator for being female estimates the gender gap in the intrinsic utility of being on a team, $b^{T}-b^{I}{ }^{27}$ The other regressor in equation (3), $\left(Y_{i}^{T}-Y_{i}^{I}\right)$, is the gap between the total monetary reward individual $i$ expects to receive if she chooses team compensation, and what she would receive if she chose individual compensation. Its coefficient, $c$, reveals the effect of financial rewards on a participant's utility.

As already noted, participant $i$ 's compensation levels under each of the two reward schemes are given respectively by:

$$
\begin{aligned}
& Y_{i}^{T}=r^{T}\left(Q_{i}^{T}+Q_{j}^{T}\right) / 2 \\
& Y_{i}^{I}=r^{I} Q_{i}^{I}
\end{aligned}
$$

where $Q_{i}^{T}$ and $Q_{j}^{T}$ denote the outputs (i.e. number of problems solved) by individual $i$ and her prospective teammate $j$ under team compensation, $Q_{i}^{I}$ is $i$ 's output under individual compensation, and $r^{T}$ and $r^{I}$ are the prices paid by the experimenter per unit of output under the two compensation schemes. ${ }^{28}$ In our B treatment, $r^{I}=r^{T}=20$. In our EA treatment, $r^{I}=20$ and $r^{T}=22$.

The precise values of $Q_{i}^{T}, Q_{j}^{T}$ and $Q_{i}^{I}$ for the current round of production are of course unknown to our participants when choosing their preferred method of compensation; thus it is

\footnotetext{
${ }^{27}$ As always in the probit context, these estimates of utility parameters are relative to the unidentified idiosyncratic variance of team preferences, $\sigma_{\varepsilon}$.

${ }^{28}$ Equation (4) gives the expected income associated with working under the team compensation regime. In Parts 5 and 6 this is distinct from the expected income associated with choosing the "team" option because both partners must agree to actually form a team. Here, $Y_{i}^{T}=p\left[r^{T}\left(Q_{i}^{T}+Q_{j}^{T}\right) / 2\right]+(1-p) Y_{i}^{I}$, where $p$ is the participant's perceived probability that her co-participant will also choose 'team'. In this case, the probit coefficients on the relative income variable should be interpreted as an estimate of $p c$, rather than $c$ (since the expected income gap is scaled by $p$ ). In practice, our estimated income-gap coefficients in Part 5 are about the same size as in Part 3, suggesting that the participants behave as if $p$ was close to one.
} 
workers' expectations of these quantities that enter into (4) and (5). ${ }^{29}$ That said, since we elicit expectations of partners' performance, and since individual output is highly stable across parts of the experiment, we have access to some remarkably effective proxies for these quantities. ${ }^{30}$ Specifically, we use each worker's own Part 1 output as our measure of his expected output under individual incentives $\left(Q_{i}{ }^{I}\right)$, his own Part 2 output as his output under team incentives $\left(Q_{i}{ }^{T}\right)$, and his estimate of his co-participant's Part 2 output for $Q_{j}{ }^{T}{ }^{31}$

\section{b) Estimates of the utility parameters}

Columns (1) and (6) of Table 5 report estimates of the probit coefficients in equation (3) for Parts 3 and $5 .^{32}$

\section{(Insert Table 5 about here)}

The coefficients on $\left(Y_{i}^{T}-Y_{i}^{I}\right)$ are estimates of the parameter $c$, and indicate that participants both perceive, and care strongly about expected financial rewards when choosing among compensation schemes. The coefficients on being female estimate the utility parameter $b$, i.e. women's intrinsic relative preference for a cooperative work environment. Controlling for the expected income gap (which incorporates the effects of gender differentials in overconfidence), columns 1 and 5 show no statistically significant gender gap in preferences for the team environment. $^{33}$

Columns (2) and (7) in Table 5 enter the participant's expected income on a team $\left(Y_{i}^{T}\right)$ and under individual compensation $\left(Y_{i}^{I}\right)$ as separate regressors rather than as a difference. If the

\footnotetext{
${ }^{29}$ The one exception occurs in Part 4, where participants are paid according to their own output in the previous part.

${ }^{30}$ The correlation between an individual's Part 1 output, and his output in Parts 2, 3, 5, and 6 respectively is .74, .75, .73, and .77. (Recall there is no production in Part 4).

${ }^{31}$ There is very little change in the results if we use Period 1 (or Period 2) quantities for all expectations.

${ }^{32}$ As already noted, Part 4 is a variation of Part 3 treatment designed to test for (the anticipation of ) moral hazard, and no (actual or expected) moral hazard is found. Part 6 is a variation of the Part 5, designed to test for the effects of (expected) communication, and no robust effect of communication was found either. To save space, we accordingly present results from only Parts 3 and 5 henceforth.

${ }^{33}$ Since our structural model assumes risk neutrality, none of the results reported in this Section include contols for risk aversion. Very little changes, however, when we add these controls.
} 
highly stylized model in equation (3) is correctly specified, these two variables should enter equally with opposite signs. This is strongly confirmed by our data: Tests of the null hypothesis of equal and opposite signed coefficients yield $p$-values of .814 and 897 for the Part 3 and 5 data respectively.

Columns (3) and (8) of Table 5 decompose the expected income gap $\left(Y_{i}^{T}-Y_{i}^{I}\right)$ in a different way. Specifically, using (4) and (5), note that the expected income gap can be written:

$$
Y_{i}^{T}-Y_{i}^{I}=Q_{i}^{T}\left(r^{T}-r^{I}\right)+r^{T}\left(Q_{j}^{T}-Q_{i}^{T}\right) / 2+r^{I}\left(Q_{i}^{T}-Q_{i}^{I}\right)
$$

The first term in this decomposition is the portion of the expected income differential between individual and team compensation that is due to efficiency advantages of team production, $\left(r^{T}\right.$ $r^{I}$ ); this component equals zero for all observations in our B treatment. The second term on the RHS of equation (6) represents the effect of (anticipated) adverse selection on the expected income gap: If I expect my partner to solve more problems than I, this term is positive and should attract me to team production. The final term gives the effects of (anticipated) moral hazard. Specifically, if I expect to perform better in a team environment than I do in an individual one, this term is positive and again disposes me towards team compensation.

Columns (3) and (8) use equation (6) to distinguish the effects of the three above sources of the expected income differential between team and individual compensation on the choice of team compensation. Now, if the model of preferences in equation (3) is correctly specified, all three of these sources of variation in the gap should have equal (same sign) coefficients. Importantly, we find that income differentials stemming from experimenter-manipulated efficiency gains and those stemming from the teammate's perceived relative ability do have the same effect on subjects' choices ( $p=.802$ and .499 in Parts 3 and 5 respectively). Thus, we cannot explain the large gap in team choice between the B and EA treatments by the notion that subjects respond to experimenter-manipulated rewards differently from rewards associated with 
subjects own perceptions of their relative ability. That said, the effects of both these sources of the expected income gaps differ significantly from the estimated effects of anticipated moral hazard $(p<.001$ in all cases). We believe that this results from the relatively poor quality of our proxy for the "moral hazard" component: it is the only component that is estimated from between-Part differences in output. ${ }^{34}$

So far, with the exception of the moral hazard coefficients, the highly stylized model of equation (3) yields coefficient estimates of the expected sign in all cases, and passes two key specification checks. But how well does this simple model account for the results from both our experimental treatments?

\section{c) Actual and predicted payment scheme choices}

Table 6 shows participants' actual team choices, plus their predicted team choices from the three models estimated so far (columns 1-3 and 6-8 of Table 5) in columns 1-3 and 7.

\section{(Insert Table 6 about here)}

Interestingly, while all models considered so far predict a large increase in team choices when team efficiency advantages are introduced, all of them encounter difficulties in explaining the size and distribution of this change. Models 1 and 2 systematically underpredict the increase for both men and women (sometimes dramatically), while Model 3 underpredicts for women and overpredicts for men, again usually by substantial magnitudes.

To explore what model elements might better account for our results, columns (4) and (9) of Table 5 allow the effects of the three components of the team-nonteam income gap to vary by gender. Perhaps unsurprisingly, the estimated effects of moral hazard are small in magnitude for

\footnotetext{
${ }^{34}$ Specifically, we are using the participant's own growth in output between Parts 1 and 2 to estimate how much his own Part 3 (or Part 5) output would differ depending on whether he chose team compensation or not. Since these Part 1 - Part 2 differences could be contaminated by learning effects, we are not surprised that measures of expected moral hazard based on them do not perform as well as our other measures of expected income gaps.
} 
both men and women, and do not differ significantly between the genders ( $p=.529$ and .152 for Parts 3 and 5 respectively). The effects of (anticipated) adverse selection are much larger in magnitude and are highly statistically significant for both men and women, but again these effects do not differ by gender ( $p=.861$ and .644 for Parts 3 and 5). Finally, however, the estimated effects of team-related efficiency gains are about twice as large for men as for women, and this gender difference is statistically significant ( $p=.046$ and .048 respectively). Notably, columns (4) and (8) also show a substantial intrinsic preference for teams among women; this differential is significant at the 5 percent level in the Part 5 data $(p=.109$ in Part 3). This result is consistent with the notion that women are disproportionately attracted to teams even after controlling for their lower levels of overconfidence, but that this attraction is masked in situations where teams have an efficiency advantage by men's greater responsiveness to this instrumental reason for joining teams.

Table 5 reports the results of one final specification in columns (5) and (10). These columns report a more parsimonious version of the preceding model in which the effects of adverse selection and moral hazard are constrained to be independent of gender. Not surprisingly, there is very little change: the only gender gap in responsiveness we need to account for our results is in responsiveness to efficiency gains. More importantly, as indicated in column (5) of Table 6, this parsimonious model does a much better job of accounting for our experimental results than any model that assumes men and women respond to efficiency gains equally.

To explore an alternative possible explanation, Table 6 presents predicted team choices from a model in which men and women once again respond equally to financial incentives, regardless of their source (experimenter-manipulated team efficiency gains versus other factors). But we now try to explain the gender gap in the response to efficiency gains by positing that the 
introduction of extrinsic rewards for team production destroys women's intrinsic motivation for teamwork. Thus, Model 6 is identical to Model 1, but the female indicator is replaced with its interaction with the B treatment. While this model fits women's behavior reasonably well (though not as well as Model 4), it still overpredicts men's team choices in the B treatment, usually by a wide margin.

\section{d) Counterfactual predictions}

Finally, to assess the relative importance of the various contributing factors to the gender team gap, Table 7 presents a number of counterfactual predictions, based on Table 6's Model 5. Column 1 presents the predictions of Model 5 at the means of the data; as already noted these fit the observed choices by gender very well. ${ }^{35}$ "Counterfactual 1" asks "How would women's choices change if they had men's beliefs about their co-participant's ability?"36 Clearly, this does not change men's predicted choices, but it reduces the rate at which women choose team compensation. According to the model, this gender difference in beliefs can account for (.147 $.034) / .147=77$ percent of the gender gap in Part 3 under the B treatment. Under the EA treatment, giving women men's beliefs reverses the gender wage gap, making women 14 percentage points less likely than men to choose team production. Likewise in Part 5, the gender-teams gap is either dramatically reduced or eliminated if we simply imagine that women were as pessimistic as men are about their teammate's relative ability. In all cases, more than half the gender gap in team formation is explained by the gender gap in beliefs.

\section{(Insert Table 7 about here)}

\footnotetext{
${ }^{35}$ In order to facilitate the counterfactual exercises, Table 7 presents predictions for a hypothetical man or woman with mean covariates for their gender. For well known reasons, these predictions differ slightly from Table 6, which presents the mean predicted probability for all men or women in the sample.

${ }^{36}$ To compute these, we take a woman with mean part 1 and part 2 performance, and assign her men's mean assessments of their partner's ability rather than her own.
} 
Counterfactual 2 asks “How would women's choices change if they responded to the prospect of team-related efficiency gains just like men?"37 By construction, such differential responses to financial incentives cannot explain the gender gap in the B treatment. On the other hand, making women as responsive to efficiency gains as men dramatically raises their team participation in the EA treatment. Thus, if women had their own (more optimistic) beliefs about their partner's ability, and at the same time were as responsive to extrinsic incentives to form teams as men are, their rates of team formation in the EA treatment (where such efficiency advantages are present) are predicted to be much higher than men's (at least 24 percentage points higher). In sum, according to our model, men's and women's roughly equal rates of team formation in the EA treatment are, in part, the net result of these two opposing forces: women are more optimistic about their partner's ability, but less responsive to the prospect of financial gain associated with team formation.

Finally, Counterfactual 3 combines the previous two thought experiments by assigning women both the beliefs and responsiveness-to-incentives of men. Any gender gap that remains should only reflect 'pure' preferences for being in a cooperative work environment. ${ }^{38}$ Interestingly, this gap is positive and substantial in magnitude in all cases, even in the EA treatment. ${ }^{39}$ We conclude that the model of preferences that best describes all of our data has the following elements: First, women $d o$ have a greater underlying preference for being in a team environment. This preference is visible in simple comparisons of means in our B treatment (where it is in fact accentuated by a gender gap in overconfidence). Second, however, this

\footnotetext{
${ }^{37}$ Specifically, we simply set the "income gap due to efficiency gains * female" coefficient in Table 5 equal to the "income gap due to efficiency gains * male" coefficient, then computed the predicted team probability for an average woman in the sample.

${ }^{38}$ Technically, gender differences in the coefficient on beliefs also play a role here, but as we have already shown these are small in magnitude and statistically insignificant.

${ }^{39}$ In Part 3 of the B treatment it is only 3.4 percentage points, but this is result of the fact that, when women have men's beliefs and no incentives are present, both genders' team-choice probabilities are close to zero. In percentage terms, women's team choice rate is double men's here.
} 
underlying preference is obscured in treatments that provide extrinsic incentives to join teams, to which men are more responsive than women.

\section{Gender and Task Performance in Endogenously-formed Teams}

\section{a) Selection and causation}

In Table 1 we compared individuals' performance when they were assigned to individual or team compensation on a mandatory basis. Despite large incentives to free ride in the team treatment, we found no evidence of moral hazard for either gender: task performance was unrelated to the pay scheme for both men and women. In this section we study whether selfselected teams do better or worse than forced teams, and how (if at all) the performance of selfselected teams differs by gender. This question may be of interest both in workplaces where a choice of team versus individual production is offered, or in understanding how men and women might make different occupational and career choices, where these options differ by the amount of teamwork that is typical.

As is well known, the performance of self-selected teams can differ from the performance of mandated teams for two sets of reasons: selection and causation. ${ }^{40}$ Concerning the former, we have already shown that abler workers, on average, are more likely to avoid teams; for this reason we should expect voluntarily-formed teams to perform more poorly than mandated teams. Further, because women are less pessimistic about their prospective teammates' ability, this selection process is weaker for women. Thus we should expect to see voluntarily-formed female teams perform better, on average, than voluntarily-formed male teams.

Turning to causation, our estimates from Parts 1 and 2 have already shown that the treatment effect of mandatory teams on task performance is essentially zero. As is well known,

\footnotetext{
${ }^{40}$ For example, Eriksson et al. (2009) show that effort increases when a tournament pay scheme is voluntarily chosen compared to when it is imposed, both for self-selection reasons and for motivational reasons.
} 
however, this does not imply that the treatment effect is zero in a sample of voluntarily-formed teams: consider, for example, a simple Roy model of sector selection (Roy 1951; Heckman and Honoré, 1990), where individuals have idiosyncratic comparative advantages in the two sectors. In particular, if teams attract people who perform relatively well in them, self-selected teams will tend to be more productive than mandated teams. One might expect, for example, that persons who are less likely to free ride, or even persons who are more likely to be motivated or inspired by the presence of a teammate, to disproportionately choose teams. ${ }^{41}$ Further, this might differ by gender, e.g. if women are less likely to free ride than men.

In this section, we first document the performance gaps between individuals who choose team compensation and those who do not, in the team-choice parts of our experiment. We then use our experimental design to distinguish the relative roles of selection versus causation in explaining those gaps. Fortunately, our experimental design allows us to non-parametrically estimate causal effects of the team environment on the sample of persons who voluntarily choose that environment (i.e. the treatment on the treated (TOT) effect: Angrist and Pischke 2009, p. 14) without any assumptions on the form of unobserved heterogeneity.

\section{b) Relative productivity of team joiners and non-joiners}

For Parts 3 and 5 of the experiment, Table 8 shows the mean performance of participants who chose team compensation and those who did not, separately by gender and treatment. ${ }^{42}$

\section{(Insert Table 8 about here)}

In seven of eight cases, team joiners performed worse on average than non-joiners; this gap is statistically significant (at $p<.001, .004$ and .058) in three cases. A naïve interpretation

\footnotetext{
${ }^{41}$ In the exit survey, 26 percent of the women who chose the team-pay in Part 3 (30 percent in Part 5) and 32 percent of men in both parts explain their choice by the belief that joining a team would motivate them to work harder. See Babcock et al. (2011) for evidence of the positive motivational effects of teams.

${ }^{42}$ Recall that, in Part 5, choosing team compensation does not necessarily result in being paid on a team basis. When we repeat the analysis only for subjects who sucessfully formed teams (because their partner also chose team compensation), they are very similar, though with a smaller sample size.
} 
of this gap might, of course, be that team production causes free riding, relative to mandatory team production. Further, the joiner-nonjoiner output gap is always larger for men than for women; and significantly so ( $p=.001$ and .028$)$ in two of the four cases. Again superficially, one might conclude from this that women are less prone to free-riding. On the other hand, we have already shown that self-selection also affect these comparisons. ${ }^{43}$

To begin to understand the effect of self-selection on the voluntary team-nonteam output gap, Table 9 shows Part 1 output separately for individuals who chose teams in Parts 3 and 5, and for individuals who did not. Overall, the patterns are very similar to Table 8: team joiners were, on average, less productive than nonjoiners even in Part 1 of the experiment, when everyone was compensated individually. And this joiner-nonjoiner "ability" gap is always greater for men than women, significantly so the same 2 of 4 times as for current-period output ( $p=.009$ and .035). This gap is never statistically significant for women. Thus, not only is there adverse selection into teams, but this selection is more pronounced among men than women. Firms thinking of offering a teamwork option might benefit from knowing this: the team environment is less likely to attract "lemons" in a female than a male work environment.

\section{(Insert Table 9 about here)}

\section{c) Causal effect of teamwork on output by gender}

Finally, what is the causal effect of working on a team for those who voluntarily choose that environment, and how does this effect differ by gender? To formalize our discussion, note that the output gap between voluntary team joiners and non-joiners in (say) Part 3 of our experiment can be expressed as:

$$
E\left(Q^{3} \mid J^{3}\right)-E\left(Q^{3} \mid N J^{3}\right)=E\left(Q^{l} \mid J^{3}\right)-E\left(Q^{l} \mid N J^{3}\right)
$$

\footnotetext{
${ }^{43}$ For example, the lower output of teams in Part 3 might be driven by a large adverse selection effect, which is partially outweighed by a positive causal effect of the team environment on performance; in addition this true causal effect might differ by gender.
} 


$$
+\quad\left[E\left(Q^{3} \mid J^{3}\right)-E\left(Q^{l} \mid J^{3}\right)\right]-\left[E\left(Q^{3} \mid N J^{3}\right)-E\left(Q^{1} \mid N J^{3}\right)\right]
$$

where $Q^{i}$ denotes the individual's performance in Part $i$, and $J^{i}$ and $N J^{i}$ respectively denote whether the participant joined or did not join a team in Part $i$.

The first term on the RHS of (7) gives the pure selection component of the performance gap between joiners and non-joiners in Part 3; it is simply the difference in Part 1 output between the participants who chose team in Part 3 and those who did not. These are the numbers already shown in Table 8, which are predominantly negative, showing adverse selection into teams. The remaining two terms in (7) are the output change between Parts 1 and 3 for Part-3 joiners, minus the output change for Part-3 non-joiners. Only the first of these changes (for joiners) is affected by a change of the production environment from an individual to a team situation, while both are affected by any task learning or pure period effects that distinguish Parts 1 and 3. Therefore, if these period and task-learning effects are the same for persons who eventually join teams and those who do not --this is our identifying assumption--, then the last two terms in (7) estimate the pure TOT effect of the team environment.

\section{(Insert Table 10 about here)}

Table 10 decomposes the team-non-team output gaps identified in Table 8 using equation (7). While the magnitudes of TOT and selection effects vary substantially across treatments and parts of the experiment, Table 10 shows clearly that selection plays the dominant role in explaining the gaps observed in Table 8: in five of the eight possible cases, selection accounts for more than 100 percent of the team-non-team output gaps; in seven of eight cases it accounts for more than half of the output gap. ${ }^{44}$ Also noteworthy is that fact that, in four of the eight cases (two involving men and two involving women), the TOT causal effect of team production is

\footnotetext{
${ }^{44}$ In one case, note that the output gap is positive rather than negative (Part 5 of the EA treatment for women).
} 
positive, not negative. This provides further support for our finding that moral hazard is essentially absent in this two-person team environment.

In sum, Tables 9 and 10 show quite conclusively that the output gaps between voluntarily-formed teams and individuals who choose to produce individually are not causal effects of the team environment, but are primarily driven by adverse selection. Further, the larger team-non-team output gaps that we see among men compared to women are not due, in any sense, to women having on average a greater comparative advantage in team production (e.g. being less prone to free riding). Instead, they result from stronger adverse selection among men, which as we showed earlier in this paper is driven by men's greater overconfidence in their own relative ability. Thus, firms offering voluntary teamwork should in general be wary of adverse selection, but should be especially wary in male workplaces: because men strongly underestimate their co-workers' ability, only the men with the very lowest productivity will tend to sign up for the teams. By the same token, one might expect men who select into "cooperative" occupations to be more adversely selected than women who do so.

\section{Discussion}

Our laboratory experiment has found that when study participants can choose between team and individual compensation, and when there is no efficiency advantage associated with team production, women choose team-based compensation more frequently than men. In contrast, as soon as we introduce even a small efficiency advantage of team production, women and men join teams with equal frequency. Using a simple structural model of tastes for teamwork, we show that the gender gap in team entry across a variety of experimental environments can be well explained by the interaction between three elements: 1) lesser pessimism among women about the relative ability of their teammate (consistent with the gender gap in confidence found notably in Barber and Odean, 2001, and Niederle and Vesterlund, 
2007); 2) a greater responsiveness among men to instrumental reasons for joining teams; and 3) a greater "pure" preference for team work among women - possibly due to a larger preference for equal sharing (Croson and Gneezy 2009), or to a stronger brain activation for social rewards such as social feedback (Spreckelmeyer et al., 2009).

Concerning the second finding, other authors have studied gender differences in responsiveness to economic incentives in a variety of contexts, with mixed results. On the one hand, there is considerable consensus that women's (uncompensated) labor supply elasticities exceed men's (Killingsworth and Heckman, 1986), though this may be largely because there is limited scope for men -most of whom work full time-- to raise their measured labor supply. On the other hand, using hypothetical questionnaires, psychologists find that men exhibit a greater sensitivity to rewards (Torrubia et al., 2001; Ray Li et al., 2007) and a higher valuation of earnings than women, possibly for evolutionary reasons (Browne, 2002; Kanasawa, 2005). In altruistic donations, Andreoni and Vesterlund (2001) have found that men's demand curve for altruism is more reactive to price changes. Finally, a field experiment by Paarsch and Shearer (2007) finds no gender gap in the response to a higher individual piece rate.

Our finding of differential responsiveness to team incentives, however, addresses a distinct question from all the above studies. Note, first of all, that all the above studies refer to responsiveness to individual incentives only. Second, and more critically, they refer to the reaction of participants' supply of work effort to incentives. If we examine this question in our data, we find no difference in men's and women's responsiveness to incentives: Table 1 shows workers' outputs under a 20-cent versus a 22-cent group piece rate. Neither men nor women produce more under the higher piece rate, possibly because both are performing at their maximum capacity in both cases. Instead, our finding refers to the choice of contractual form: men seem to have a baseline relative aversion to the team environment if there is no (economic) 
point in joining it, but this aversion is easily counterbalanced by the prospect of even a small economic reward. Overall, our results on voluntary teaming contribute to the theory that men and women tend to build different types of social relationships (this has been developed for both human and non-human primates by Low, 1999; see also Bond and Vinacke, 1961; and Seabright, 2011), but they also show that differences may disappear when economic factors become more salient. This could be supported by the fact that during adolescence, men tend to develop a stronger concern for efficiency while females become more attracted by equal sharing (Almas et al., 2010).

The implications of our results for the prospects of redesigning well-paid jobs to make them more attractive to women might, in at least one way, be seen as disappointing. While it is true that women seem to have, on average, a greater affinity for co-operative work environments, our results show that, whenever there is even a small instrumental reason for joining teams (such as the efficiency gains in our experiment) men will be at least as attracted to the team environment as women, though for different reasons. That said, if a goal of job design is to compose gender-balanced work environments, teams may be an attractive contractual form, although at the cost of attracting less-talented men. ${ }^{45}$

Moving beyond job design, we also note that our results confirm those of many other authors who have found that, on average, women have more accurate assessments of their own relative abilities, primarily because women do not underestimate their peers' abilities as much. While more accurate assessments may not be performance-enhancing in all contexts -optimism can of course be motivating - this suggests that women might, on average, have an advantage in

\footnotetext{
${ }^{45}$ Note also that preferences for competition and cooperation are not necessarily negatively correlated; it is not necessarily the women who dislike competition who are more attracted by teamwork. Further study of these correlations might provide additional insights into questions of optimal job design.
} 
any situation where accurate assessment of others' abilities is a key to success, including for example financial markets (Barber and Odean, 2001).

Aside from these possible prescriptive implications, our results might also help shed light on the substantial and continuing gap in the occupational distribution of men and women, even in societies where a great deal of equality of opportunity exists. As is well known, women are highly overrepresented in the nonprofit sector and in helping occupations (Powell and Steinberg, 2006), both of which involve cooperative production with little associated prospect of financial reward. These are precisely the conditions where the gender gap in voluntary team participation (in women's favor) was the largest in our experiment. 


\section{References}

Almas, Ingvild, Alexander W. Capppelen, Erik O. Sorensen, and Bertil Tungodden. "Fairness and the Development of Inequality Acceptance.” Science, 328(5982), 1176-1178. 28 May 2010.

Andersen, Steffen, Erwin Bulte, Uri Gneezy, and John A. List. "Do Women Supply More Public Goods than Men? Preliminary Experimental Evidence from Matrilineal and Patriarchal Societies" American Economic Review: Papers \& Proceedings. 98(2), 376-381. 2008.

Andreoni, James, and Lise Vesterlund. "Which Is the Fair Sex? Gender Differences in Altruism". The Quarterly Journal of Economics 116 (1), 293-312. February 2001.

Angrist, Joshua D., and Jörn-Steffen Pischke. Mostly Harmless Econometrics: An Empiricist's Companion. Princeton, NJ: Princeton University Press. 2009.

Apesteguia, Jose, Ghazala Azmat, and Nagore Iriberri. "The Impact of Gender Composition on Team Performance and Decision-Making: Evidence from the Field". Unpublished paper, Universitat Pompeu Fabra. July 2010

Babcock, Linda and Sara Laschever. Women Don't Ask: Negotiation and the Gender Divide Princeton: Princeton University Press. 2003.

Babcock, Philip, Kelly Bedard, Gary Charness, John Hartman, and Heather Royer. "Letting Down the Team? Evidence of Social Effects of Team Incentives". NBER working paper no. 16687. January 2011.

Balafoutas, Lukas, and Matthias Sutter, "Affirmative action policies have a double dividend". Mimeo, University of Innsbruck. 2011.

Bandiera, Oriana, Iwan Barankay, and Imran Rasul. "Team Incentives: Evidence from a Field Experiment”. Unpublished paper, University of Pennsylvania. October 2009.

Barber, Brad M., and Terrance Odean. "Boys Will Be Boys: Gender, Overconfidence, and Common Stock Investment." The Quarterly Journal of Economics, 261-292. 2001

Bond, John R., and W. Edgard Vinacke. Coalitions in Mixed-Sex Triads. Sociometry (24), 61-75. 1961.

Boning, Brent, Casey Ichniowski, and Kathryn Shaw "Opportunity Counts: Teams and the Effectiveness of Production Incentives" Journal of Labor Economics 25(4), 613-650. October 2007.

Booth, Alison L., and Patrick J. Nolen. "Gender Differences in Risk Behavior: Does Nurture Matter?" IZA Discussion Paper no. 4026. March 2009a.

Booth, Alison L., and Patrick J. Nolen. “Choosing to Compete: How Different Are Girls and Boys?” IZA Discussion Paper no. 4027. March 2009b.

Bornstein, Gary, Uri Gneezy, and Rosemarie Nagel. "The effect of intergroup competition on intragroup coordination: An experimental study." Games and Economic Behavior 41, 1-25. 2002.

Boschini, Anne, and Anna Sjogren. "Is Team Formation Gender Neutral? Evidence from Coauthorship Patterns.” Journal of Labor Economics 25 (2), 325-365. April 2007. 
Brown, Martin, Armin Falk and Ernst Fehr. "Relational Contracts and the Nature of Market Interactions." Econometrica 72(3), 747-780. May 2004.

Browne, Kingsley R. Biology at work: Rethinking sexual equality. New-Brunswick: Rutgers University Press. 2002.

Charness, Gary, and Martin Dufwenberg. "Promises and Partnership.” Econometrica 74(6), 1579-1601. November 2006.

Charness, Gary, and Chun-Lei Yang. "Endogenous Group Formation and Public Goods Provision: Exclusion, Exit, Mergers, and Redemption." Department of Economics, UC Santa Barbara, Working Paper no.13-08. 2008.

Charness, Gary, David Masclet, and Marie Claire Villeval. "Competitive Preferences and Status as an Incentive: Experimental Evidence.” IZA Discussion Paper no.5034. June 2010.

Croson, Rachel, and Uri Gneezy. "Gender Differences in Preferences." Journal of Economic Literature 47(2), 448-474. June 2009.

Dargnies, Marie-Pierre. "Team competition : Eliminating the gender gap in competitiveness." Unpublished manuscript. September 2010.

Datta Gupta, Nabanita, Anders Poulsen, and Marie Claire Villeval. "Gender matching and competitiveness : Experimental evidence." Forthcoming in Economic Inquiry. 2011.

Delfgaauw, Josse, Robert Dur, Joeri Sol, and Willem Verbeke. "Tournament Incentives in The Field: Gender Differences in The Workplace.” Tinbergen Institute Discussion Papers no. 09-069/1. 2009.

Eckel, Catherine C., and Philip J. Grossman. "Differences in the economic decisions of men and women: experimental evidence." In Charles R. Plott and Vernon L. Smith (Eds.). Handbook of Experimental Results. Vol.1, 509-519. 2008.

Eriksson, Tor, Sabrina Teyssier, and Marie Claire Villeval. "Does Self-Selection Improve the Efficiency of Tournaments?” Economic Inquiry, 87(3), 530-548, 2009.

Friebel, Guido, and Paul Seabright. "Do women have longer conversations? Telephone evidence of gendred communication strategies.” Journal of Economic Psychology 32(3), 348-356. June 2011.

Garratt, Rodney J., Catherine Weinberger and Nick Johnson. "The State Street Mile: Age and Gender Differences in Competition Aversion in the Field." Forthcoming in Economic Inquiry. 2011.

Gneezy, Uri and Aldo Rustichini. "Gender and Competition at a Young Age." American Economic Review 94(2), 377-381. May 2004.

Gneezy, Uri, Kenneth L. Leonard and John A. List. "Gender Differences in Competition: Evidence from a Matrilineal and a Patriarchal Society." Econometrica 77, 1637-1664. 2009.

Gneezy, Uri, Muriel Niederle, and Aldo Rustichini. "Performance in Competitive Environments: Gender Differences. The Quarterly Journal of Economics 118(3), 1049-1074. August 2003. 
Greiner, B. "An online recruitment system for economic experiments." In Forschung und wissenschaftliches Rechnen GWDG Bericht 63, Ed. K. Kremer, and V. Macho. Göttingen: Gesellschaft fu $\square \mathrm{r}$ Wissenschaftliche Datenverarbeitung. 2004.

Graves, Laura M., and Gary N. Powell. "Sex, Sex Similarity and Sex Diversity Effects in Teams: The Importance of Situational Factors." In Bilimoria, Diana, and Sandy Kristin Piderit (Eds.,) Handbook on Women in Business and Management. Cheltenham, U.K. and Northampton, Mass.: Elgar. 217-31. 2007.

Hamilton, Barton, Jack Nickerson, and Hideo Owan. "Team Incentives and Worker Heterogeneity: An Empirical Analysis of the Impact of Teams on Productivity and Participation." Journal of Political Economy 111(3), 465-497. June 2003.

Healy, Andrew, and Jennifer Pate. "Can Teams Help to Close the Gender Competition Gap?" Forthcoming in The Economic Journal. 2011.

Heckman, James J., and Bo E. Honoré. "The Empirical Content of the Roy Model." Econometrica 58(5), 1121-1149. September 1990.

Holt, Charles A., and Susan K. Laury. "Risk Aversion and Incentive Effects. " American Economic Review 92 (5), 1644-1655. December 2002.

Ivanova-Stenzel, Radosveta, and Dorothea Kübler. "Gender Differences in Team Work and Team Competition.” Forthcoming in Journal of Economic Psychology. 2011.

Kanasawa, Satoshi. "Is 'discrimination' necessary to explain the sex gap in earnings?" Journal of Economic Psychology 26, 269-287. 2005.

Kandel, Eugene, and Edward Lazear. (1992). "Peer Pressure and Partnerships," Journal of Political Economy 100(4): 801-817.

Killingsworth, Mark, and James J. Heckman. "Female Labor Supply: A Survey", in Orley Ashenfelter and Richard Layard, eds., Handbook of Labor Economics, volume 1, 1986 (103-204).

Knez, Marc, and Duncan I. Simester "Firm-Wide Incentives and Mutual Monitoring at Continental Airlines." Journal of Labor Economics 19(4), 743-772. October 2001.

Kocher, Martin, Strauss, and Matthias Sutter. "Individual or team decision-making - Causes and consequences of self-selection". Games and Economic Behavior 56(2), 259-270. 2006.

Lazear, Edward P. "Globalisation and the Market for Team-Mates." Economic Journal 109(454), C1540. March 1999.

Ledyard, J. O. "Public goods: A survey of experimental research", in J. Kagel and A. Roth, eds., Handbook of Experimental Economics Princeton: Princeton University Press, 1995.

Low, Bobbi S. Why Sex Matters: A Darwinian Look at Human Behavior. Princeton: Princeton University Press. 2000.

Niederle, Muriel, and Lise Vesterlund. "Do Women Shy Away from Competition? Do Men Compete Too Much?” The Quarterly Journal of Economics 122(3), 1067- 1101. August 2007. 
Paarsch, Harry J., and Bruce S. Shearer. "Do women react differently to incentives? Evidence from experimental data and payroll records." European Economic Review 51, 1682-1707. 2007.

Plott, Charles R. and Vernon L. Smith, editors. Handbook of Experimental Economics Results, vol. 1. Amsterdam, North Holland (2008).

Powell, Walter W., and Richard Steinberg (Eds.). The Non-Profit Sector: A Research Handbook. $2^{\text {nd }}$ edition. Yale University Press. 2006.

Ray Li, Chiang-shan, Chen-Ying Huang, Wei-yu Lin, and Ching-Wen Vincent Sun. "Gender diffferences in punishment and reward sensitivity in a sample of Taiwanese college students." Personality and Individual Differences 43, 475-483. 2007.

Roy, A. D. "Some Thoughts on the Distribution of Earnings." Oxford Economic Papers 3(2), 135-146. 1951.

Schwieren, Christiane, and Mattias Sutter. "Trust in Cooperation or Ability? An Experimental Study on Gender Differences.” Economics Letters 99 (3), 494-497. June 2008.

Seabright, Paul. The Tender war: Cooperation and Conflict between Men and Women. Unpublished manuscript. June 2011.

Spreckelmeyer, Katja N., Sören Krach, Gregor Kohls, Lena Rademacher, Arda Irmak, Kerstin Konrad, Tilo Kircher, and Gerhard Gründer. "Anticipation of monetary and social reward differently activates mesolimbic brain structures in men and women." Scan 4, 158-165. 2009.

Sutter, Matthias, Ronald Bosman, Martin Kocher, and Franz van Winden. "Gender pairing and bargaining - Beware the same sex!" Experimental Economics 12(3), 318-331. 2009.

Sutter, Matthias, and Daniela Rützler. "Gender differences in competition emerge early in life: Three-year old girls compete as much as boys, but older girls don't." Unpublished manuscript. University of Innsbruck. 2010.

Torrubia, R., A.C., Avilab, J. Moltob, and X. Caserasa. "The Sensitivity to Punishment and Sensitivity to Reward Questionnaire (SPSRQ) as a measure of Gray's anxiety and impulsivity dimensions." Personality and Individual Differences 31, 837-862. 2001.

Wozniak, Daniel, William T. Harbaugh, and Ulrich Mayr. "The Menstrual Cycle and Performance Feedback Alter Gender Differences in Competitive Choices." University of Oregon Economics Department Working Paper. 2010.

Zeiliger, Romain. "A Presentation of Regate, Internet Based Software for Experimental Economics." http://www.gate.cnrs.fr/ zeiliger/regate/RegateIntro.ppt., GATE. 2000. 
Table 1: Task Performance under Mandatory Individual versus Mandatory Team Pay, by Treatment

\begin{tabular}{lccc}
\hline & $\begin{array}{c}(1) \\
\text { Part 1: } \\
\text { Individual } \\
\text { Compensation }\end{array}$ & $\begin{array}{c}(2) \\
\text { Part 2: } \\
\text { Team } \\
\text { Compensation }\end{array}$ & $\begin{array}{c}\text { (3) } \\
\text { betwalue for difference }\end{array}$ \\
\hline $\begin{array}{l}\text { A. Baseline Treatment } \\
\text { Women }\end{array}$ & 56.93 & 57.95 & .065 \\
Men & 54.83 & 55.98 & .073 \\
$p$-value for gender gap & .093 & .127 & \\
B. Efficiency Advantage Treatment & & & .089 \\
Women & 54.88 & 55.84 & .813 \\
Men & 55.49 & 55.29 & \\
$p$-value for gender gap & .624 & .685 & \\
\hline
\end{tabular}

Note: Sample sizes are 44 women and 42 men in the B treatment and 43 women and 45 men in the EA treatment. $P$-values are from 2 -sided $t$-tests for differences between means.

Table 2: Beliefs Regarding Partner's Task Performance under Mandatory Individual versus Mandatory Team Pay, by Treatment

\begin{tabular}{lccc}
\hline & $\begin{array}{c}(1) \\
\text { Part 1: } \\
\text { Individual } \\
\text { Compensation }\end{array}$ & $\begin{array}{c}(2) \\
\text { Part 2: } \\
\text { Team } \\
\text { Compensation }\end{array}$ & $\begin{array}{c}\text { (3) } \\
\text { betwalue for difference } \\
\text { A. Baseline Treatment }\end{array}$ \\
$\begin{array}{l}\text { Women } \\
\text { Men }\end{array}$ & 55.14 & 56.39 & .045 \\
$p$-value for gender gap & 50.26 & 52.10 & .002 \\
B. Efficiency Advantage Treatment & .000 & .001 & \\
Women & & & .013 \\
Men & 53.88 & 55.16 & .002 \\
$p$-value for gender gap & 51.47 & 52.78 & \\
\hline
\end{tabular}

Note: Sample sizes are 44 women and 42 men in the B treatment and 43 women and 45 men in the EA treatment. $P$-values are from 2 -sided $t$-tests for differences between means. 
Table 3: Linear Probability Model Estimates of the Probability of Choosing Team Pay, Baseline Treatment

\begin{tabular}{lccccc}
\hline Variables & $(1)$ & $(2)$ & $(3)$ & $(4)$ \\
& Part 3 & Part 4 & Part 5 & $\begin{array}{c}(5) \\
\text { Part 6 }\end{array}$ & $\begin{array}{c}\text { Team choice } \\
\text { Parts }\end{array}$ \\
\hline Female & .0972 & -.0035 & $.2686^{* *}$ & $.2315^{*}$ & $.6825^{* * *}$ \\
& $(.0835)$ & $(.0733)$ & $(.1017)$ & $(.1168)$ & $(.2866)$ \\
Own Part 1 output & $-.0182^{* *}$ & $-.0304^{* * *}$ & $-.0249 * * *$ & -.0152 & $-.0866^{* * *}$ \\
& $(.0075)$ & $(.0066)$ & $(.0088)$ & $(.0101)$ & $(.0249)$ \\
Beliefs re. Partner's & $.0183^{* *}$ & $.0262^{* * *}$ & .0086 & -.0102 & .0394 \\
Part 1 output & $(.0087)$ & $(.0077)$ & $(.0103)$ & $(.0118)$ & $. .0290)$ \\
Control for risk preferences & $Y e s$ & $Y e s$ & $Y e s$ & $Y e s$ & Yes \\
\hline Observations & 86 & 86 & 76 & 76 & 76 \\
R-squared & .147 & .245 & .264 & .108 & .241 \\
\hline
\end{tabular}

$* * * \mathrm{p}<0.01, * * \mathrm{p}<0.05, * \mathrm{p}<0.1 .$. Standard errors are in parentheses. The number of observations is 76 in Models 3 to 5 because of a technical breakdown in one session (see footnote 11).

Table 4: Linear Probability Model Estimates of the Probability of Choosing Team Pay, Efficiency Advantage Treatment

\begin{tabular}{|c|c|c|c|c|c|}
\hline Variables & $\begin{array}{c}(1) \\
\text { Part } 3\end{array}$ & $\begin{array}{c}(2) \\
\text { Part } 4\end{array}$ & $\begin{array}{c}(3) \\
\text { Part } 5\end{array}$ & $\begin{array}{c}(4) \\
\text { Part } 6\end{array}$ & $\begin{array}{c}\text { (5) } \\
\text { Team } \\
\text { choice Parts } \\
\end{array}$ \\
\hline Female & $\begin{array}{c}-.1738 * \\
(.1013)\end{array}$ & $\begin{array}{l}-.0551 \\
(.1040)\end{array}$ & $\begin{array}{l}-.0437 \\
(.0943)\end{array}$ & $\begin{array}{c}.0040 \\
(.0900)\end{array}$ & $\begin{array}{l}-.2686 \\
(.2988)\end{array}$ \\
\hline Own Part 1 output & $\begin{array}{c}-.0474 * * * \\
(.0107)\end{array}$ & $\begin{array}{c}-.0412 * * * \\
(.0110)\end{array}$ & $\begin{array}{c}-.0308 * * * \\
(.0100)\end{array}$ & $\begin{array}{c}-.0357 * * * \\
(.0095)\end{array}$ & $\begin{array}{c}-.1551 * * * \\
(.0317)\end{array}$ \\
\hline Beliefs re. Partner's & $.0520 * * *$ & $.0509 * * *$ & $.0433 * * *$ & $.0416 * * *$ & $.1878 * * *$ \\
\hline Part 1 output & $(.0120)$ & $(.0123)$ & $(.0111)$ & $(.0106)$ & $(.0353)$ \\
\hline Control for risk preferences & Yes & Yes & Yes & Yes & Yes \\
\hline Observations & 88 & 88 & 88 & 88 & 88 \\
\hline R-squared & .245 & .210 & .182 & .211 & .303 \\
\hline
\end{tabular}

$* * * \mathrm{p}<0.01, * * \mathrm{p}<0.05, * \mathrm{p}<0.1 .$. Standard errors are in parentheses. 
Table 5: Estimates of Utility Parameters from ML Models

\begin{tabular}{|c|c|c|c|c|c|c|c|c|c|c|}
\hline & (1) & (2) & $\begin{array}{c}(3) \\
\text { PART } 3\end{array}$ & (4) & (5) & (6) & (7) & $\begin{array}{c}(8) \\
\text { PART } 5\end{array}$ & (9) & (10) \\
\hline Female $\left(F_{i}\right)$ & $\begin{array}{c}.0281 \\
(.2106)\end{array}$ & $\begin{array}{c}.0347 \\
(.2125)\end{array}$ & $\begin{array}{c}-.0056 \\
(.2283)\end{array}$ & $\begin{array}{c}.6376 \\
(.3973)\end{array}$ & $\begin{array}{c}.5965 \\
(.3869)\end{array}$ & $\begin{array}{c}.3030 \\
(.2101)\end{array}$ & $\begin{array}{c}.3060 \\
(.2113)\end{array}$ & $\begin{array}{c}.3772 \\
(.2332)\end{array}$ & $\begin{array}{l}.9500 * * \\
(.3731)\end{array}$ & $\begin{array}{l}.8644 * * \\
(.3624)\end{array}$ \\
\hline Income Gap $\left(Y_{i}^{T}-Y_{i}^{I}\right)$ & $\begin{array}{c}.0064 * * * \\
(.0012)\end{array}$ & & & & & $\begin{array}{c}.0058 * * * \\
(.0012)\end{array}$ & & & & \\
\hline Team Income $\left(Y_{i}^{T}\right)$ & & $\begin{array}{c}.0063 * * * \\
(.0013)\end{array}$ & & & & & $\begin{array}{c}.0057 * * * \\
(.0013)\end{array}$ & & & \\
\hline Individual Income $\left(Y_{i}^{I}\right)$ & & $\begin{array}{c}-.0065^{* * *} * \\
(.0013)\end{array}$ & & & & & $\begin{array}{c}-.0058 * * * \\
(.0012)\end{array}$ & & & \\
\hline Income Gap Due to: & & & & & & & & & & \\
\hline Efficiency gains $\left(Q_{i}^{T}\left(r^{T}-r^{I}\right)\right)$ & & & $\begin{array}{c}.0119 * * * \\
(.0021)\end{array}$ & & & & & $\begin{array}{c}.0128 * * * \\
(.0021)\end{array}$ & & \\
\hline Adverse selection $\left(.5 r^{T}\left(Q_{j}^{T}-Q_{i}^{T}\right)\right)$ & & & $\begin{array}{c}.0126 * * * \\
(.0025)\end{array}$ & & $\begin{array}{c}.0133 * * * \\
(.0026)\end{array}$ & & & $\begin{array}{c}.0109 * * * \\
(.0024)\end{array}$ & & $\begin{array}{c}.0114 * * * \\
(.0024)\end{array}$ \\
\hline Moral hazard $\left(r^{I}\left(Q_{i}^{T}-Q_{i}^{I}\right)\right)$ & & & $\begin{array}{c}.0038 * * * \\
(.0015)\end{array}$ & & $\begin{array}{c}.0041 * * * \\
(.0015)\end{array}$ & & & $\begin{array}{c}.0018 \\
(.0016)\end{array}$ & & $\begin{array}{c}.0018 \\
(.0016)\end{array}$ \\
\hline Efficiency gains $*$ male & & & & $\begin{array}{c}.0177 * * * \\
(.0038)\end{array}$ & $\begin{array}{c}.0172 * * * \\
(.0035)\end{array}$ & & & & $\begin{array}{c}.0181 * * * \\
(.0036)\end{array}$ & $\begin{array}{c}.0172 * * * \\
(.0033)\end{array}$ \\
\hline Efficiency gains* female & & & & $\begin{array}{c}.0084 * * * \\
(.0028)\end{array}$ & $\begin{array}{c}.0084 * * * \\
(.0027)\end{array}$ & & & & $\begin{array}{c}.0091 * * * \\
(.0028)\end{array}$ & $\begin{array}{c}.0094 * * * \\
(.0028)\end{array}$ \\
\hline Adverse selection $*$ male & & & & $\begin{array}{c}.0141 * * * \\
(.0038)\end{array}$ & & & & & $\begin{array}{c}.0132 * * * \\
(.0035)\end{array}$ & \\
\hline Adverse selection $*$ female & & & & $\begin{array}{c}.0132 * * * \\
(.0038)\end{array}$ & & & & & $\begin{array}{c}.0108 * * * \\
(.0038)\end{array}$ & \\
\hline Moral hazard * male & & & & $\begin{array}{l}.0051 * * \\
(.0022)\end{array}$ & & & & & $\begin{array}{l}.0041 * \\
(.0023)\end{array}$ & \\
\hline Moral hazard $*$ female & & & & $\begin{array}{c}.0031 \\
(.0022)\end{array}$ & & & & & $\begin{array}{l}-.0005 \\
(.0023)\end{array}$ & \\
\hline Observations & 174 & 174 & 174 & 174 & 174 & 164 & 164 & 164 & 164 & 164 \\
\hline
\end{tabular}

*** $\mathrm{p}<0.01, * * \mathrm{p}<0.05, * \mathrm{p}<0.1$. Standard errors are in parentheses. "Income gap" refers to the gap between what the participant would earn under team compensation and individual compensation, given his/her beliefs. Part 5 has fewer observations than columns because of a technical breakdown in one session (see footnote 11). 
Table 6: Actual and Predicted Share of Subjects Choosing Team Pay, various ML models

\begin{tabular}{lccccccc}
\hline & $\begin{array}{c}(1) \\
\text { Model 1 }\end{array}$ & $\begin{array}{c}(2) \\
\text { Model 2 }\end{array}$ & $\begin{array}{c}(3) \\
\text { Model 3 }\end{array}$ & $\begin{array}{c}(4) \\
\text { Model 4 }\end{array}$ & $\begin{array}{c}(5) \\
\text { Model 5 }\end{array}$ & $\begin{array}{c}(6) \\
\text { Model 6 }\end{array}$ & $\begin{array}{c}(7) \\
\text { Actual }\end{array}$ \\
\hline PART 3: & & & & & & & \\
Women & & & & & & & \\
$\quad$ Baseline & .262 & .262 & .181 & .235 & .237 & .239 & .227 \\
$\quad$ Efficiency Advantages & .511 & .510 & .601 & .537 & .537 & .512 & .535 \\
$\quad$ Change: & .249 & .248 & .419 & .302 & .300 & .273 & .308 \\
Men & & & & & & & \\
$\quad$ Baseline & .228 & .231 & .124 & .071 & .069 & .239 & .071 \\
$\quad$ Efficiency Advantages & .410 & .408 & .497 & .555 & .555 & .422 & .556 \\
$\quad$ Change: & .182 & .177 & .373 & .484 & .486 & .182 & .484 \\
PART 5: & & & & & & & \\
Women & & & & & & & \\
$\quad$ Baseline & .474 & .474 & .349 & .413 & .411 & .409 & .410 \\
$\quad$ Efficiency Advantages & .707 & .707 & .829 & .775 & .776 & .664 & .767 \\
$\quad$ Change: & .234 & .233 & .480 & .362 & .365 & .256 & .357 \\
Men & & & & & & & \\
$\quad$ Baseline & .332 & .334 & .169 & .116 & .109 & .383 & .108 \\
$\quad$ Efficiency Advantages & .518 & .516 & .632 & .684 & .684 & .576 & .689 \\
$\quad$ Change: & .186 & .183 & .463 & .568 & .575 & .192 & .581 \\
\hline
\end{tabular}

Model 1 is estimated in columns 1 and 5 of Table 5; Model 2 in columns 2 and 6, etc. 
Table 7: Predicted and Counterfactual Shares of Subjects Choosing Team Pay, Model 5

\begin{tabular}{lcccc}
\hline & $\begin{array}{c}(1) \\
\text { Predicted }\end{array}$ & $\begin{array}{c}(2) \\
\text { Counter- } \\
\text { factual 1 }\end{array}$ & $\begin{array}{c}(3) \\
\text { Counter- } \\
\text { factual 2 }\end{array}$ & $\begin{array}{c}(4) \\
\text { Counter- } \\
\text { factual 3 }\end{array}$ \\
\hline Part 3: & & & & \\
B Treatment & .183 & .071 & .183 & .071 \\
$\quad$ Women & .036 & .036 & .036 & .036 \\
$\quad$ Men & .147 & .034 & .147 & .034 \\
$\quad$ Gender Gap & .555 & .417 & .870 & .781 \\
EA Treatment & .558 & .558 & .558 & .558 \\
$\quad$ Women & -.003 & -.141 & .312 & .223 \\
$\quad$ Men & & & & \\
$\quad$ Gender Gap & .386 & .217 & .386 & .217 \\
Part 5: & .079 & .079 & .079 & .079 \\
B Treatment & .307 & .139 & .307 & .139 \\
$\quad$ Women & & & & \\
$\quad$ Men & .802 & .708 & .957 & .922 \\
$\quad$ Gender Gap & .713 & .713 & .713 & .713 \\
EA Treatment & .088 & -.005 & .244 & .209 \\
$\quad$ Women & & & & \\
$\quad$ Men & & & & \\
$\quad$ Gender Gap & &
\end{tabular}

Note: Counterfactual 1 gives women men's beliefs regarding their partner's ability. Counterfactual 2 makes women respond to extrinsic motivation the same as men. Counterfactual 3 does both. 
Table 8: Mean Performance of Subjects, by Choice of Team Pay and Treatment

\begin{tabular}{|c|c|c|c|c|c|c|c|c|}
\hline & \multicolumn{4}{|c|}{ PART 3} & \multicolumn{4}{|c|}{ PART 5} \\
\hline & (1) & (2) & (3) & (4) & (5) & (6) & (7) & (8) \\
\hline & $\begin{array}{l}\text { Non- } \\
\text { joiners }\end{array}$ & Joiners & $\begin{array}{c}\text { Gap } \\
(2)-(1)\end{array}$ & $\begin{array}{l}p \text {-value } \\
\text { for gap }\end{array}$ & $\begin{array}{l}\text { Non- } \\
\text { Joiners }\end{array}$ & Joiners & $\begin{array}{c}\text { Gap } \\
(6)-(5)\end{array}$ & $\begin{array}{l}p \text {-value } \\
\text { for gap }\end{array}$ \\
\hline \multicolumn{9}{|l|}{ B Treatment: } \\
\hline Women & 59.32 & 56.90 & -2.42 & .203 & 60.48 & 58.38 & -2.10 & .119 \\
\hline $\mathrm{N}$ & 34 & 10 & 44 & & 23 & 16 & 39 & \\
\hline Men & 58.18 & 47.33 & -10.85 & .004 & 60.00 & 49.50 & -10.50 & .000 \\
\hline $\mathrm{N}$ & 39 & 3 & 42 & & 33 & 4 & 37 & \\
\hline$p$-value for gender gap & .385 & .020 & .001 & & .704 & .003 & .028 & \\
\hline \multicolumn{9}{|l|}{ EA Treatment: } \\
\hline Women & 57.70 & 56.43 & -1.27 & .418 & 57.40 & 57.70 & .30 & .865 \\
\hline $\mathrm{N}$ & 20 & 23 & 43 & & 10 & 33 & 43 & \\
\hline Men & 58.80 & 54.80 & -4.00 & .058 & 58.36 & 56.52 & -1.84 & .372 \\
\hline $\mathrm{N}$ & 20 & 25 & 45 & & 14 & 31 & 45 & \\
\hline$p$-value for gender gap & .536 & .380 & .272 & & .724 & .379 & .438 & \\
\hline
\end{tabular}

Notes: In Part 3, joining denotes the participant's decision to be paid via team compensation; in Part 5 this only results in team compensation being paid if the co-participant also chose team compensation; however performance levels are very similar for the (smaller) sample who actually formed teams. All $p$-values are from 2-sided $t$-tests for differences between means, except those for the gender gap in joiner-nonjoiner difference. These come from a Chi-squared test that accounts for the fact that the underlying joiner-nonjoiner difference is itself a difference in sample means.

Table 9: Mean Part 1 Performance of Subjects, by Choice of Team Pay in Parts 3 and 5

\begin{tabular}{|c|c|c|c|c|c|c|c|c|}
\hline & \multicolumn{4}{|c|}{ PART 3} & \multicolumn{4}{|c|}{ PART 5} \\
\hline & (1) & (2) & (3) & (4) & (5) & (6) & (7) & (8) \\
\hline & $\begin{array}{c}\text { Non- } \\
\text { joiners }\end{array}$ & Joiners & $\begin{array}{c}\text { Gap } \\
(2)-(1)\end{array}$ & $\begin{array}{l}p \text {-value } \\
\text { for gap }\end{array}$ & $\begin{array}{l}\text { Non- } \\
\text { Joiners }\end{array}$ & Joiners & $\begin{array}{c}\text { Gap } \\
(6)-(5)\end{array}$ & $\begin{array}{l}p \text {-value } \\
\text { for gap }\end{array}$ \\
\hline \multicolumn{9}{|l|}{ B Treatment: } \\
\hline Women & 57.15 & 56.20 & -0.95 & .624 & 57.83 & 55.56 & -2.26 & .218 \\
\hline $\mathrm{N}$ & 34 & 10 & 44 & & 23 & 16 & 39 & \\
\hline Men & 55.49 & 46.33 & -9.15 & .011 & 56.30 & 45.75 & -10.55 & .001 \\
\hline $\mathrm{N}$ & 39 & 3 & 42 & & 33 & 4 & 37 & \\
\hline$p$-value for gender gap & .212 & .011 & .009 & & .311 & .004 & .035 & \\
\hline \multicolumn{9}{|l|}{ EA Treatment: } \\
\hline Women & 56.05 & 53.87 & -2.18 & .214 & 53.90 & 55.18 & 1.28 & .539 \\
\hline $\mathrm{N}$ & 20 & 23 & 43 & & 10 & 33 & 43 & \\
\hline Men & 57.05 & 54.24 & -2.81 & .110 & 57.64 & 54.52 & -3.13 & .097 \\
\hline $\mathrm{N}$ & 20 & 25 & 45 & & 14 & 31 & 45 & \\
\hline$p$-value for gender gap & .527 & .838 & .789 & & 200 & .615 & .146 & \\
\hline
\end{tabular}

Notes: See Table 8. 
Table 10: Decomposition of Performance Gap between Joiners and Non-Joiners, Parts 3 and 5.

\begin{tabular}{ccccccc}
\hline & $(1)$ & $(2)$ & $(3)$ & $(4)$ & $(5)$ & $(6)$ \\
\hline & $\begin{array}{c}\text { Gap due to } \\
\text { selection }\end{array}$ & $\begin{array}{c}\text { Gap due to } \\
\text { behavioral } \\
\text { change }\end{array}$ & $\begin{array}{c}\text { Total } \\
\text { gap }\end{array}$ & $\begin{array}{c}\text { Gap due to } \\
\text { selection }\end{array}$ & $\begin{array}{c}\text { Gap due to } \\
\text { behavioral } \\
\text { change }\end{array}$ & $\begin{array}{c}\text { Total } \\
\text { gap }\end{array}$ \\
\hline B Treatment & & & & & & \\
Women & -.95 & -1.48 & -2.42 & -2.26 & .16 & -2.10 \\
$\%$ & 39.08 & 60.92 & 100.00 & 107.62 & -7.62 & 100.00 \\
Men & -9.15 & -1.69 & -10.85 & -10.55 & .05 & -10.50 \\
$\%$ & 84.40 & 15.60 & 100.00 & 100.51 & -0.51 & 100.00 \\
EA Treatment & & & & & & \\
Women & -2.18 & 0.92 & -1.27 & 1.28 & -.98 & .30 \\
$\%$ & 172.34 & -72.34 & 100.00 & 431.64 & -331.64 & 100.00 \\
Men & -2.81 & -1.19 & -4.00 & -3.13 & 1.29 & -1.84 \\
$\%$ & 70.25 & 29.75 & 100.00 & 169.84 & -69.84 & 100.00 \\
\hline
\end{tabular}




\begin{tabular}{|c|c|c|c|c|c|}
\hline $\begin{array}{l}\text { 1. Imposed Indiv. } \\
\text { compensation (I) }\end{array}$ & $\begin{array}{l}\text { 2. Imposed Team } \\
\text { (T) for } 02 \text { and } 02 \text { ' }\end{array}$ & $\begin{array}{l}\text { 3. Choice (I, T) } \\
\text { for } 03 \text { and } 02 \text {, }\end{array}$ & $\begin{array}{l}\text { 4. Choice (I, T) } \\
\text { for } 01 \text { and } 01 \text { ' }\end{array}$ & $\begin{array}{l}\text { 5. Choice (I, T) } \\
\text { for } 05 \text { and } 05^{\prime} \\
\mathrm{T} \text { if both choose } \mathrm{T}\end{array}$ & $\begin{array}{l}\text { 6. Choice (I, T) } \\
\text { for o6 and o6' } \\
\text { T if both choose T }\end{array}$ \\
\hline Task & Task & Task & No task & Task & $\begin{array}{c}\text { Communication - } \\
\text { Task }\end{array}$ \\
\hline
\end{tabular}

Figure 1. Sequence of Decisions

Note: o means output and o' indicates the partner's output. $\mathrm{T}$ is for the team compensation, and I for the individual compensation. 


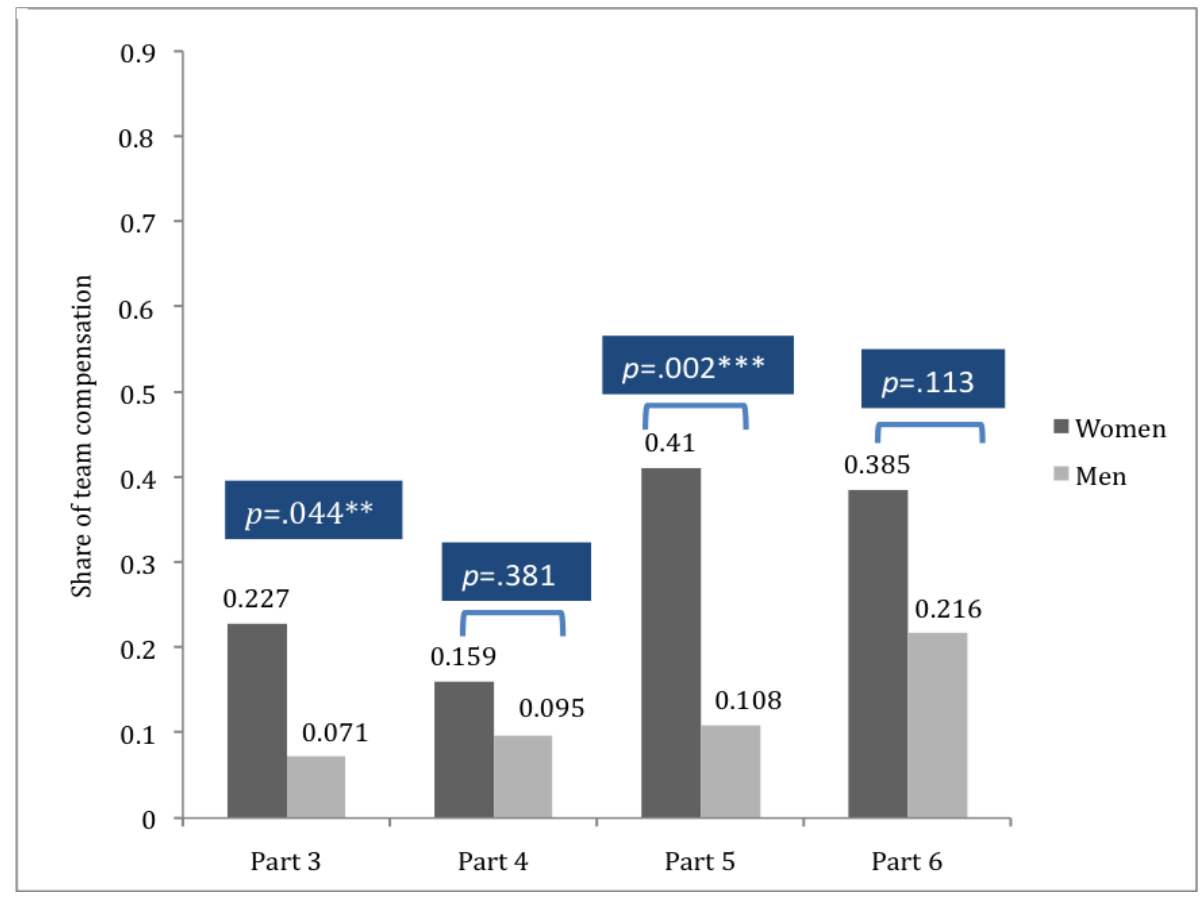

Figure 2. Share of Participants Choosing Team Compensation, by Gender, B Treatment

Note: In Part 3, the output is matched with the partner's Part 2 output. In Part 4, the output in Part 1 is matched with the partner's Part 1 output. In Part 5, the output is matched with the current partner's output. Part 6 is similar to Part 5, except that communication precedes performance. $P$-values are from two-tailed $t$-tests.

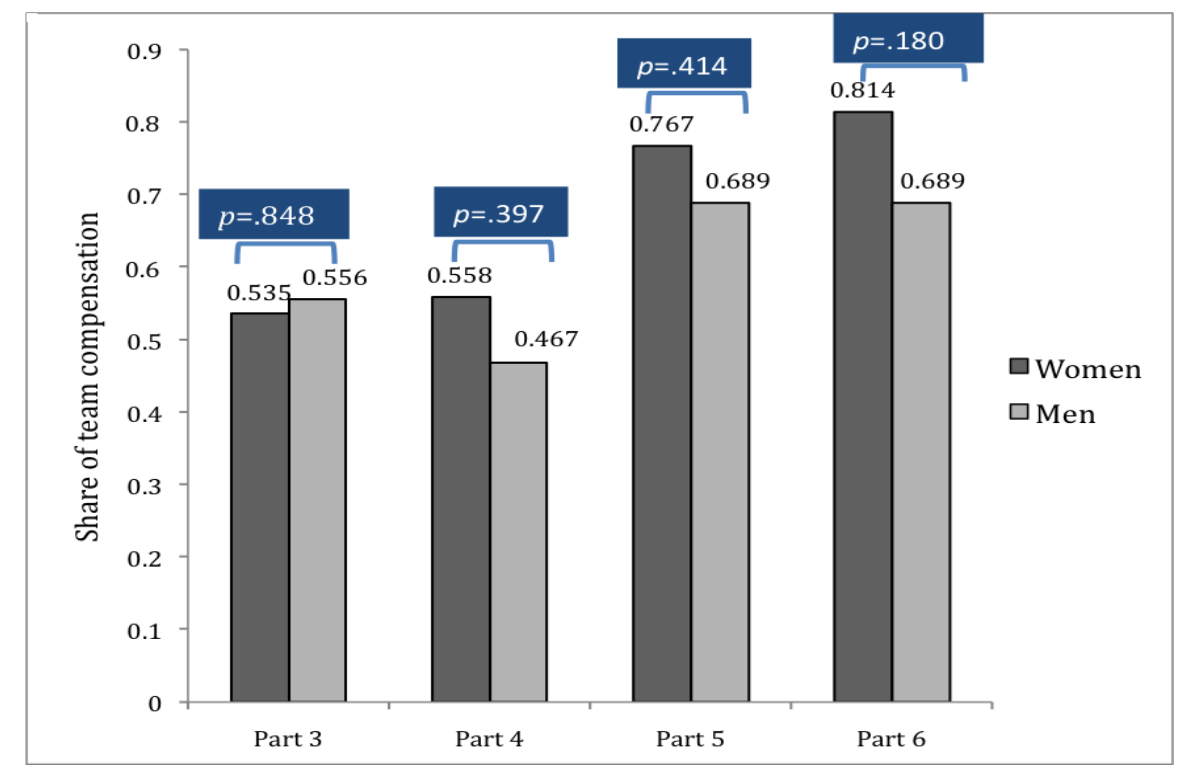

Figure 3. Share of Participants Choosing Team Compensation, by Gender, EA Treatment

Note: In Part 3, the output is matched with the partner's Part 2 output. In Part 4, the output in Part 1 is matched with the partner's Part 1 output. In Part 5, the output is matched with the current partner's output. Part 6 is similar to Part 5, except that communication precedes performance. $P$-values are from two-tailed $t$-tests. 


\section{Appendix 1. Instructions for the B treatment (Original in French. The instructions for the EA treatment are similar except that the team payment is 22 Euro-cents instead of 20)}

You are about to participate in an experimental session on decision-making. During this session, you can earn money. In addition, you will receive $€ 3$ for showing up on time. Your earnings will be paid to you in cash privately at the end of the session.

The session consists of several parts. You have received the instructions for the preliminary part. The instructions for the next parts will be distributed after you have completed the preliminary part.

\section{Preliminary part}

Your computer screen will display ten decisions, as indicated in the table below.

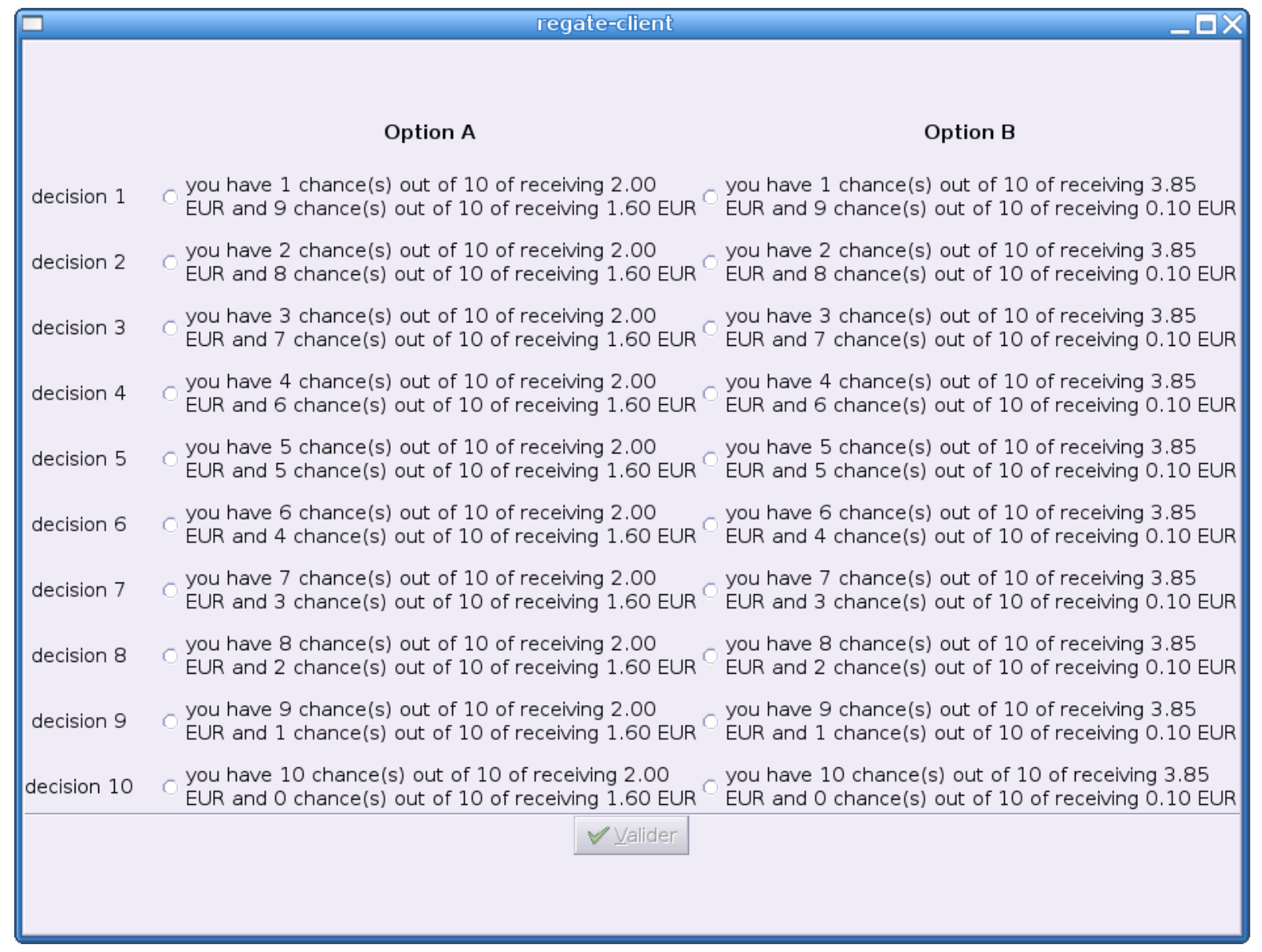

Each decision is a paired choice between "Option A" (on the left) and "Option B" (on the right). You will make ten choices between option A and option B, but only one of them will be used in the end of the session to determine your earnings for this part. You will not know in advance which decision will be used. Obviously, each decision has an equal chance of being used in the end. Before you start making your ten choices, please let me explain how these choices will affect your earnings for this part.

Look at Decision 1. Option A pays $2 €$ with 1 chance out of 10 , and it pays $1.6 €$ with 9 chances out of 10 . Option B yields $3.85 €$ with 1 chance out of 10 , and it pays $0.1 €$ with 9 chances out of 10 . The other decisions are similar, except that as you move down the table, the chances of a higher payoff for each option increase. For 
example, look at Decision 2. Option A pays $2 €$ with 2 chances out of 10 , and it pays $1.6 €$ with 8 chances out of 10. Option B yields $3.85 €$ with 2 chances out of 10 , and it pays $0.1 €$ with 8 chances out of 10 . In fact, for Decision 10, each option pays the highest payoff for sure, so your choice here is between $2 €$ and $3.85 €$.

Once you have made your ten decisions, you must validate them by pressing the «validate » button.

At the end of the session, the computer program will randomly select one of the ten decisions. For this decision, a second random draw will determine your earnings for the option you have chosen. Earnings in Euros for this choice will be added to your other earnings.

Please read these instructions again and raise your hand if you have any question. We shall answer to your questions in private. It is strictly forbidden to talk with the other participants during the session.

\section{Instructions (contd) (Instructions distributed after completion of the preliminary part)}

The remaining of the session consists of six parts. In most of these parts, you will be asked to complete a task. The method we use to determine your earnings varies across parts, as explained in detail at the beginning of each part.

At the end of the session, once you have completed these parts, we will randomly draw one part out of six for determining your payment. Each part has the same chance to be selected. Your payment in this part will be added to your payment from the preliminary part and your show-up fee.

In this experiment, participants are located in two adjacent rooms. At the beginning of the first part, each participant in each room will be paired with one participant located in the other room. You will only be told the first name of this participant and this participant will learn your first name. You will remain matched with the same co-participant throughout the rest of the session.

In order to protect your privacy and that of your co-participant, at the end of the session participants in the two rooms will be dismissed at different times.

\section{Part 1}

At the beginning of this part, you enter your first name in the computer and you will be informed on the first name of your co-participant who is located an the other room.

The task consists of converting letters into numbers during 4 minutes. Your screen displays a table with two columns. The first column indicates letters and the second column indicates their correspondence in numbers. You are given a letter and you must enter the corresponding number in the box on your screen. You must validate your answer by pressing the 'Execute' button. Once you have validated your answer, you are immediately informed whether your answer is correct or not.

As soon as you have validated an answer, whether it is correct or not, the conversion table of letters and numbers is modified and a new letter to convert is displayed on your screen. You can convert as many letters as you like during the four-minute period of time.

During these four minutes, and in all future time periods allocated to the task in this experiment, you are allowed to read a book or a magazine that you have brought with you or to surf on the Internet. To access the Internet, you can press the "Internet" button located at the top left of your screen; you can come back to the task whenever you like, by pressing the "task" button located at the same place.

If part 1 is the one randomly selected for payment, you will get 20 Euro-cents per problem you solve correctly in these 4 minutes. Your payment does not decrease if you provide an incorrect answer to a problem. We refer to this payment as the individual payment scheme. 
- Before we start, you are given a chance to practice this task during three minutes to familiarize yourself with the task. The number of problems solved during this practice period will not affect your earnings.

- Then you can convert letters into numbers during 4 minutes.

- As in all parts of the experiment, you will be informed on the number of problems you have personally solved correctly (your "score") at the end of this part. You will not learn your co-participant's score in this or in any other part until the very end of the session: At that time, regardless of which part is selected for payment, you will be informed of your co-participant's score in that part.

Please read these instructions again. If you have any questions, please raise your hand.

\section{Part 2 (Instructions distributed after completion of Part 1)}

You remain matched with the same co-participant. As in Part 1 you will be given 4 minutes to convert letters into numbers. As before, you are allowed to read a book or to surf on the Internet.

But for this task your payment depends on your performance and on the performance of your co-participant.

If Part 2 is the one randomly selected for payment, then both you and your co-participant's earnings are determined as follows:

Your earnings $=$ Co-participant's earnings $=\_\underline{€ .20 *(\text { Work Team output })}$

\section{2}

where Work Team output is the total number of problems correctly solved by you plus the number correctly solved by your co-participant. Thus, the work team is paid 20 Euro-cents for every question solved by its members, together. This amount is then divided equally between the two work team members. We refer to this payment scheme as the team payment.

To understand how the team payment scheme differs from the individual payment scheme, please read the following examples:

Suppose, for example, that you and your co-participant each solve 40 problems. Then in the team payment scheme each of you will be paid $(0.20 * 80) / 2=€ 8$, which is the same as you would receive in the individual payment scheme.

If, on the other hand, you solve 50 problems and your co-participant solves 30, you would till be paid $(0.20 * 80) / 2=€ 8$ under team payment, but you (personally) would have received $0.20 * 50=€ 10$ under the individual payment scheme.

Likewise, if you were to solve 30 problems but your co-participant 50 , you would both still be paid $(0.20 * 80) / 2$ $=€ 8$ under team payment, compared to the $.20 * 30=€ 6$ you (personally) would receive under the individual payment scheme.

As before, at the end of this part, you will only be informed on the total number of problems that you have personally solved. If this part is selected for payment you will learn your co-participant's number of problems solved after all six parts have been completed.

If you have any questions, please raise your hand.

Before we begin the work period, please answer the following comprehension questions. 


\section{Comprehension questionnaire}

1. If you solved 50 problems, how much would you be paid in the individual payment scheme we used in Part 1 ?

2. If you solved 60 problems, how much would you be paid in the individual payment scheme we used in Part 1 ?

3. If you solved 40 problems, how much would you be paid in the individual payment scheme we used in Part 1 ?

4. If you and your co-participant each solve 50 problems, how much will you be paid in the team payment scheme used in this part?

5. If you solve 60 problems and your co-participant solves 40 , how much will you be paid in the team payment scheme used in this part?

6. If you solve 40 problems and your co-participant solves 60 , how much will you be paid in the team payment scheme used in this part?

\section{Part 3 (Instructions distributed after completion of Part 2)}

As in the previous two parts you will be given 4 minutes to convert letters into numbers.

But now, before starting the task, you will get to choose which of the two previous payment schemes you prefer to apply to your performance.

If Part 3 is the one randomly selected for payment, then your earnings are determined as follows.

- If you choose the individual payment scheme, you receive 20 Euro-cents per problem you personally solve correctly in this part.

- If you choose the team payment scheme, we will use your co-participant's output in the previous part (Part 2) to determine your work team's output. (We do this because your co-participant might not choose team payment this part). In other words, your work team's output in this part equals your own output in this part plus your co-participant's output in Part 2. As before, the team is paid 20 Euro-cents for every unit of team output. This amount is then divided equally between the two team members, so your earnings are again given by:

$$
\text { Your earnings }=\_€ \frac{€ 0.20 *(\text { Work Team output })}{2} \text {. }
$$

As before, at the end of this part you will only be informed on the total number of problems that you have personally solved. If this part is selected for payment, you will learn your co-participant's number of problems solved after all six parts have been completed. You will learn your co-participant's score in this part regardless of whether you choose team or individual compensation.

If you have any questions, please raise your hand.

\section{Part 4 (Instructions distributed after completion of Part 3)}

You do not have to convert any letters into numbers for the fourth part of the experiment. Instead, if Part 4 is the one selected for payment, you will be paid one more time for the number of problems you (and possibly your co-participant) solved in Part 1. Recall that, in Part 1, both you and your co-participant were paid according to the individual payment scheme. 
But you now have to choose which payment scheme you want applied to the number of problems that were solved correctly in Part 1. You can either choose to be paid according to the individual payment scheme, or according to the team payment scheme.

If the Part 4 is the one selected for payment, then your earnings are determined as follows.

- If you choose the individual payment scheme, you receive 20 Euro-cents per problem you solve correctly in Part 1.

- If you choose the team payment scheme, your team's performance will equal your performance in Part 1 plus your co-participant's performance in Part 1 . As before, the team is paid 20 Euro-cents times team output, which is then divided equally between you and your co-participant.

The next computer screen will remind you how many problems you personally solved correctly in Part 1, and will ask you to choose whether you want the individual payment scheme or the team payment scheme applied to your performance. As always, you will not learn the number of problems correctly solved by your coparticipant until all parts of this experiment are completed; this holds whatever your choice in this part.

If you have any questions, please raise your hand.

\section{Interim Questions (Instructions distributed after completion of Part 4)}

We would now like to ask you some questions about the number of problems you estimate that your coparticipant solved in the experiment so far. Thinking back to Parts 1 and 2, how many problems do you think your co-participant solved correctly?

You earn 0.50 Euro more for each correct prediction in questions 1 and 3 (plus or minus 1 problem solved).

1. Number of problems you estimate your co-participant solved in Part 1 (Recall that in Part 1, each person worked on their own, and was paid 20 Euro-cents per problem solved):

2. To determine how confident you are you of your estimate in Question 1, please select a number from 1 to 5 , where 5 indicates you believe your estimate is extremely accurate, and 1 indicates you really have no idea of what your co-participant produced.

3. Number of problems you estimate your co-participant solved in Part 2 (Recall that in Part 2, each person worked on a team with their co-participant; each team was paid 20 cents per problem solved, which was shared equally between the co-participants).

4. To determine how confident you are of your estimate in Question 3, please select a number from 1 to 5 , where 5 indicates you believe your estimate is extremely accurate, and 1 indicates you really have no idea of what your co-participant produced.

\section{Part 5 (Instructions distributed after completion of the interim questionnaire)}

You will again be given 4 minutes to convert letters into numbers.

Before this, you will again have to choose which of the two possible payment schemes will be applied to your performance in this part. Next, we will tell you which payment scheme your co-participant selected. The team payment is used only if both you and your co-participant choose it. 
If Part 5 is the one randomly selected for payment, then your earnings are determined as follows.

- If you choose the individual payment scheme, you receive 20 Euro-cents per problem you personally solve correctly in this part.

- If you AND your co-participant both choose the team payment scheme, your team's performance will equal your performance in this part plus your co-participant's performance in this part. As always, the team is paid 20 Euro-cents times team output, which is then divided equally between you and your co-participant.

- If one of you chooses the individual payment scheme and the other one chooses the team payment scheme, both you and your co-participant are paid the individual payment scheme. Therefore, you receive 20 Eurocents per problem you personally solve correctly in this part.

The next computer screen will ask you to choose between the individual payment scheme or the team payment scheme. Then, you will be informed of the choice of your co-participant. Last, you will then be given 4 minutes to convert letters into numbers. As always, reading books or magazines or surfing on the Internet is allowed during this time.

If you have any questions, please raise your hand.

Part 6 (Instructions distributed after completion of Part 5)

You will again be given 4 minutes to convert letters into numbers. Everything is exactly the same as in Part 5, except that persons who form teams will have an opportunity to communicate with each other before starting the task.

As before, you will begin by choosing which of the two possible payment schemes you prefer to apply to your performance in this part. Next, we will tell you which payment scheme your co-participant selected. The team payment is used only if both you and your co-participant choose it.

If both you AND your co-participant have chosen the team payment, you are given two minutes to exchange instant messages with your co-participant, before performing the task. A box will appear on your screen in which you can type your messages. The messages must not include information that could identify you or your co-participant; they must not be threatening; and they must use an appropriate language.

Note that this box will also appear on your screen even if you and your co-participant do not form a team, i.e. even if one or both of you selected the individual payment scheme. In this case, you may type any message you want, but your messages will not be transmitted to your co-participant.

If Part 6 is the one randomly selected for payment, then your earnings are determined as in Part 5.

- The next computer screen will ask you to choose whether you want individual payment scheme or the team payment scheme applied to your performance.

- Then, whatever your choice, you will be informed of the choice of your co-participant.

- When applicable, you have two minutes to exchange instant messages with your co-participant.

- Last, you will be given 4 minutes to convert letters into numbers. Reading books or magazines or surfing on the Internet is allowed during this time.

After this part has been completed, you will have to answer a few last questions and your screen will give you a feedback on your payments in the preliminary part and in the part between 1 and 6 that has been drawn randomly. If you have any questions, please raise your hand. 
Exit questionnaire (Displayed on the computer screen at the very end of the session before feedback on payoffs; note that the same questionnaire was displayed regarding choices in Part 5, except that we added an item, mentioned in italics in the following list))

In Part 1, you were paid under an individual payment scheme; in Part 2, you were paid under a team payment scheme. At the beginning of Part 3, you chose between being paid under an individual or a team payment scheme. Could you explain why you chose/avoided the team payment scheme at that time?

I chose not to work on a team because (choose all that apply):

-I was concerned that my partner might not be very good at this task.

-I was concerned that my partner might not like to work very hard at this task.

-I was concerned that being on a team would give my partner a chance to be paid without working very hard

-I thought that working on my own would motivate me more

-I prefer to work on my own rather than working on a team

-I did not want to 'compete' with my co-participant to know which would have the best performance

- I did not want to be embarrassed if I chose team compensation but may partner did not

-Other (please describe)

I chose to work on a team because (choose all that apply):

-I thought my partner might be quite good at this task

-I thought my partner might like to work quite hard at this task

-Being on a team gives me an opportunity to be paid even if I don't work very hard

-I thought that being on a team might motivate me more

-I thought that being on a team might motivate my partner more

-I prefer to be part of a team rather than just working on my own

-I thought it would be fun to 'compete' with my co-participant for the best performance

-I did not want to disappoint my partner in case he/she wanted to form a team

-Other (please describe) 
Appendix 2. Supplementary Tables

Table A1: Task Performance and Beliefs by Partner's Gender, $\mathrm{B}$ and EA Treatments Combined.

\begin{tabular}{lcccc}
\hline & $\begin{array}{c}(1) \\
\text { Part 1: } \\
\text { Individual } \\
\text { Compensation }\end{array}$ & $\begin{array}{c}(2) \\
\text { Part 2: } \\
\text { Team } \\
\text { Compensation }\end{array}$ & $\begin{array}{c}(3) \\
p \text {-value for } \\
\text { difference } \\
\text { between Parts } \\
1 \text { and 2 }\end{array}$ & Sample Size \\
\hline A. Own, Actual Performance & 56.21 & 57.32 & .041 & 38 \\
Women, female partner & 55.69 & 56.59 & .109 & 49 \\
Women,male partner & .669 & .523 & & 49 \\
$p$-value for partner gender effect & 55.27 & 56.49 & .041 & 38 \\
Men, female partner & 55.05 & 54.50 & .560 & \\
Men,male partner & .870 & .189 & & 38 \\
$p$-value for partner gender effect & & & & 49 \\
& & & & \\
B. Beliefs re Partner's Performance & 53.63 & 54.92 & .005 & 49 \\
Women, female partner & 55.20 & 56.45 & .046 & 38 \\
Women,male partner & .187 & .231 & & \\
$p$-value for partner gender effect & 50.63 & 51.71 & .012 & .000 \\
Men, female partner & 51.21 & 53.39 & & \\
Men,male partner & .558 & .149 & & \\
$p$-value for partner gender effect & & & & \\
\hline
\end{tabular}

